\title{
Angiotensin-converting enzyme 2, angiotensin-(1-7) and Mas: new players of the renin-angiotensin system
}

\author{
Robson A S Santos ${ }^{1}$, Anderson J Ferreira ${ }^{2}$, Thiago Verano-Braga ${ }^{1,3}$ and Michael Bader ${ }^{4}$ \\ Departments of ${ }^{1}$ Physiology and Biophysics and ${ }^{2}$ Morphology, Biological Sciences Institute, Federal University of \\ Minas Gerais, Belo Horizonte, MG, Brazil \\ ${ }^{3}$ Department of Biochemistry and Molecular Biology, University of Southern Denmark, Odense, Denmark \\ ${ }^{4}$ Max-Delbrück Center for Molecular Medicine (MDC), Robert-Rössle-Street 10, 13125 Berlin, Germany
}

Correspondence should be addressed to M Bader

Email

mbader@mdc-berlin.de

\begin{abstract}
Angiotensin (Ang)-(1-7) is now recognized as a biologically active component of the reninangiotensin system (RAS). Ang-(1-7) appears to play a central role in the RAS because it exerts a vast array of actions, many of them opposite to those attributed to the main effector peptide of the RAS, Ang II. The discovery of the Ang-converting enzyme (ACE) homolog ACE2 brought to light an important metabolic pathway responsible for Ang-(1-7) synthesis. This enzyme can form Ang-(1-7) from Ang II or less efficiently through hydrolysis of Ang I to Ang-(1-9) with subsequent Ang-(1-7) formation by ACE. In addition, it is now well established that the $\mathrm{G}$ protein-coupled receptor Mas is a functional binding site for Ang-(1-7). Thus, the axis formed by ACE2/Ang-(1-7)/Mas appears to represent an endogenous counterregulatory pathway within the RAS, the actions of which are in opposition to the vasoconstrictor/ proliferative arm of the RAS consisting of ACE, Ang II, and AT, receptor. In this brief review, we will discuss recent findings related to the biological role of the ACE2/Ang-(1-7)/Mas arm in the cardiovascular and renal systems, as well as in metabolism. In addition, we will highlight the potential interactions of Ang-(1-7) and Mas with $A T_{1}$ and $A T_{2}$ receptors.
\end{abstract} Key Words

\author{
- Angiotensin II \\ - ACE2 \\ - Mas \\ - Cardiovascular functions \\ - Metabolism
}

\section{Introduction}

Santos et al. (1988) described the formation of the heptapeptide angiotensin (Ang)-(1-7) from Ang I by an Ang-converting enzyme (ACE)-independent pathway. In the same year, Schiavone et al. (1988) published the first report of a biological action of this heptapeptide in vitro, release of vasopressin from hypothalamus-neurohypophyseal explants. One year later, Chappell et al. (1989) discovered the peptide in the rat brain and CampagnoleSantos et al. (1989) described the first in vivo action of Ang-(1-7) using microinjection in the nucleus tractus solitarii (nTS) of anesthetized rats. These seminal studies and many others that followed led to the recognition of Ang-(1-7) as a biologically active peptide of the reninangiotensin system (RAS; Carey \& Siragy 2003, Santos et al. 2005, Ferrario 2006, Bader 2010).

The identification of the ACE homolog, ACE2, as a key Ang-(1-7)-forming enzyme unravels the existence of a distinct enzymatic pathway for the production of this peptide (Donoghue et al. 2000, Tipnis et al. 2000). This monocarboxypeptidase can remove the amino acid leucine from the C-terminus of Ang I to form the biologically active peptide Ang-(1-9) (Donoghue et al.

Published by Bioscientifica Ltd. 
2000, Ocaranza et al. 2006), which is subsequently cleaved to generate Ang-(1-7) through ACE and neutral endopeptidase 24.11 (NEP) hydrolysis (Rice et al. 2004). However, apparently the generation of Ang-(1-7) directly from Ang II through the cleavage of the C-terminal amino acid phenylalanine is physiologically and biochemically more relevant (Vickers et al. 2002). Therefore, ACE2 plays a pivotal role in the body as an endogenous regulator of the RAS, once it can degrade Ang II, a vasoconstrictor/proliferative peptide, and produce Ang-(1-7), a vasodilator/ antiproliferative peptide. It should be pointed out, however, that other enzymes can form Ang-(1-7) from Ang I or Ang II, including prolylendopeptidase, prolylcarboxypeptidase, thimet oligopeptidase, and NEP (Chappell et al. 1998, Stanziola et al. 1999, Campbell et al. 2004; Fig. 1). In particular NEP may contribute substantially to the plasma levels of the heptapeptide (Chappell et al. 2000).

Another important step to establish the relevance of Ang-(1-7) was achieved with the identification of its receptor, the G protein-coupled receptor Mas (Santos et al. 2003b). This finding confirmed previous evidence obtained in functional studies (Campagnole-Santos et al. 1992, Santos et al. 2000) and with the use of the Ang-(1-7) antagonists A-779 (Ambuhl et al. 1994, Santos et al. 1994) and D-Pro ${ }^{7}$-Ang-(1-7) (Santos et al. 2003a), suggesting that this peptide exerts its actions through binding to a receptor distinct from $\mathrm{AT}_{1}$ and $\mathrm{AT}_{2}$ receptors.

It is now accepted that the ACE2/Ang-(1-7)/Mas axis is able to counteract most of the deleterious actions of the
$\mathrm{ACE} / \mathrm{Ang} \mathrm{II} / \mathrm{AT}_{1}$ receptor axis especially in pathological conditions (Ferreira \& Santos 2005; Fig. 2). However, the role of Ang-(1-7) is not limited to its counterregulatory action. Indeed, genetic deletion of Mas produces an extremely rich phenotype which includes cardiac dysfunction (Santos et al. 2006), increased blood pressure (genetic background dependent) (Xu et al. 2008), decreased baroreflex function (de Moura et al. 2010), endothelial dysfunction (Xu et al. 2008), reduced reproductive function, increased thrombogenesis (Fraga-Silva et al. 2008) and, depending on genetic background, marked changes in lipid and glucose metabolism leading to a metabolic syndrome like state (Santos et al. 2006; Fig. 3). Most of these observations are corroborated by data obtained with ACE2-deficient mice (Crackower et al. 2002, Yamamoto et al. 2006, Jin et al. 2012).

In this review, we will briefly highlight recent findings concerning the cardiovascular, renal, and metabolic roles of the ACE2/Ang-(1-7)/Mas axis. Furthermore, we will address the potential interactions of Ang-(1-7) and Mas with $\mathrm{AT}_{1}$ and $\mathrm{AT}_{2}$ receptors.

\section{Cardiac actions of the ACE2/Ang-(1-7)/Mas axis}

The presence and synthesis of RAS components in the heart suggest that locally produced bioactive Ang peptides modulate cardiac function and structure (Grinstead \& Young 1992, Dostal \& Baker 1999). Ang-(1-7) is among the RAS components present in hearts. The localization and

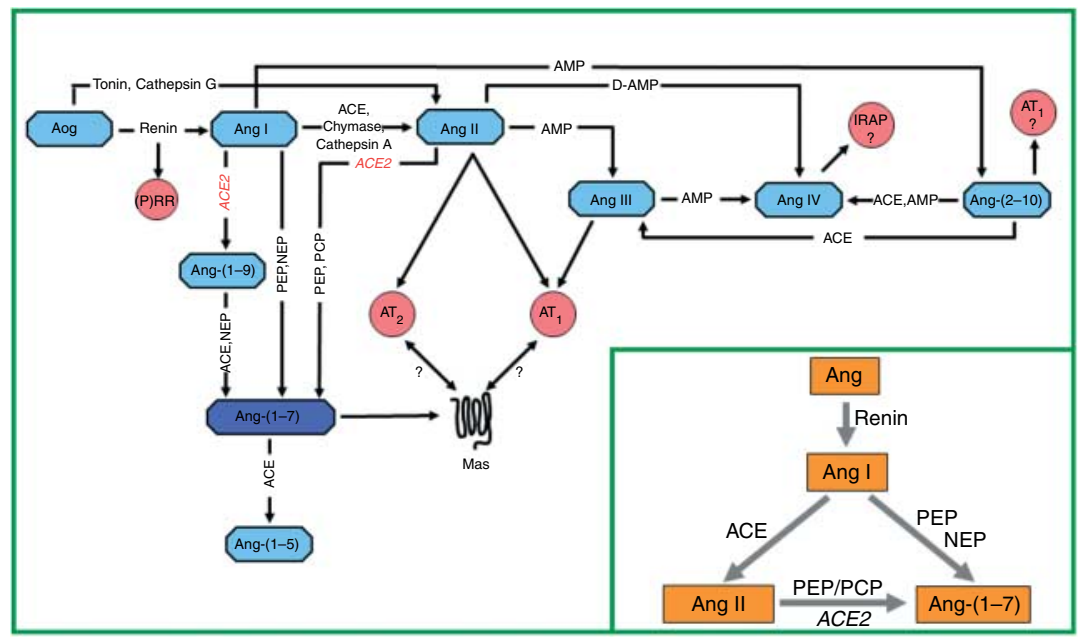

\section{Figure 1}

Detailed representation of the renin-angiotensin system cascade. The metabolic pathways involved in the generation of the main products of this system are focused in the insert. ACE, angiotensin-converting enzyme; Ang, angiotensin; Aog, angiotensinogen; AMP, aminopeptidase; $\mathrm{AT}_{1}$,
Ang II type 1 receptor; $\mathrm{AT}_{2}$, Ang II type 2 receptor; Mas, Ang-(1-7) receptor; D-Amp, dipeptidyl-aminopeptidase; IRAP, insulin regulated aminopeptidase; PCP, prolylcarboxypeptidase; PEP, prolylendopeptidase; NEP, neutral endopeptidase 24.11; (P)RR, (pro)renin receptor. http://joe.endocrinology-journals.org DOI: 10.1530/JOE-12-0341
(C) 2013 Society for Endocrinology Printed in Great Britain
Published by Bioscientifica Ltd 


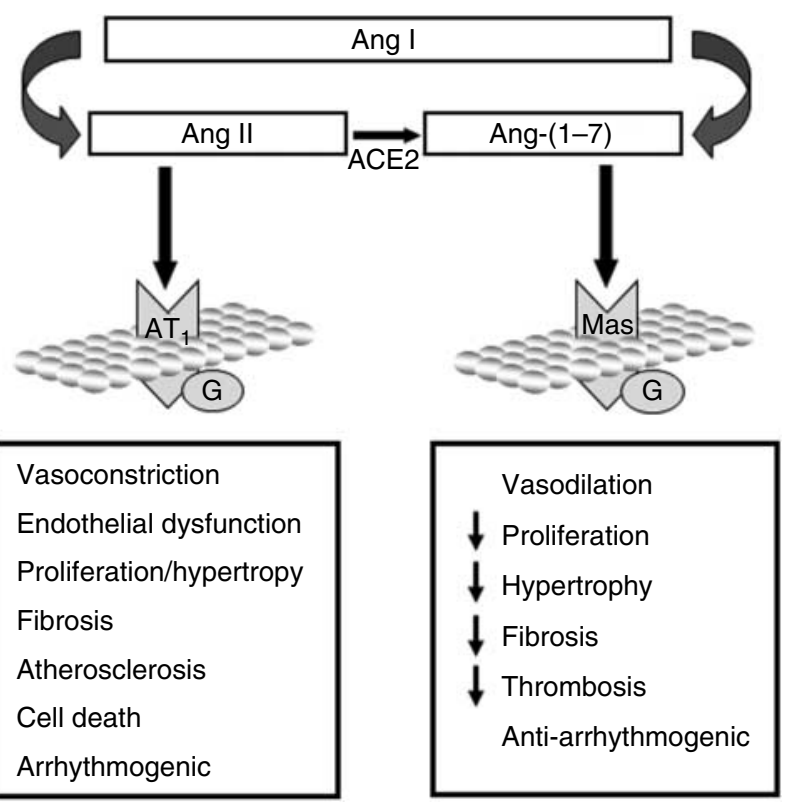

\section{Figure 2}

Opposing cardiovascular effects of the two major peptides of the reninangiotensin system, Ang II and Ang-(1-7). The intersection between these two arms of the system is the angiotensin-converting enzyme 2 (ACE2), since this enzyme can cleave the vasoconstrictor/proliferative peptide Ang II to form the vasodilator/antiproliferative fragment Ang-(1-7). $\mathrm{AT}_{1}$, Ang II type 1 receptor; Mas, Ang-(1-7) receptor. Ang, angiotensin.

local generation of Ang-(1-7) have been demonstrated in hearts from dogs (Santos et al. 1990), rats (Neves et al. 1995, Mahmood et al. 2002, Averill et al. 2003, Mendes et al. 2005) and human (Zisman et al. 2003, Campbell et al. 2004). Immunoreactive Ang-(1-7) was found in aortic root, coronary sinus and right atrium of dogs at basal conditions and its levels were markedly reduced following treatment with the ACE inhibitor CGS-14831 (Santos et al. 1990). Ang I is extensively metabolized during a single pass through the coronary bed leading to the generation of Ang II, Ang III, Ang IV and Ang-(1-7) in isolated hearts from normal (Neves et al. 1995, Mahmood et al. 2002) and diabetic rats (Mahmood et al. 2002). In addition, immunohistochemical staining revealed that Ang-(1-7) is expressed in rat cardiac myocytes (Averill et al. 2003) and sinoatrial node cells (Ferreira et al. 2012). Ang-(1-7) is also formed in human hearts and ACE inhibitors markedly decrease Ang-(1-7) generation, suggesting a substrate preference for Ang II (Zisman et al. 2003) although contrasting evidence has also been presented (Campbell et al. 2004), which may be due to the different tissue preparations (homogenates or coronary bed) used in both studies. Of note, the Ang-(1-7) receptor Mas, mRNA and protein (Metzger et al. 1995, Santos et al. 2006, Ferreira et al. 2012), is localized in cardiac tissues as well as ACE2, the main Ang-(1-7)-forming enzyme utilizing Ang II as substrate (Harmer et al. 2002, Garabelli et al. 2008, Ferreira et al. 2012).

Recent studies report that ACE2 is an important regulator of cardiac pathophysiology (Crackower et al. 2002, Yamamoto et al. 2006). However, it should be stressed that the role of ACE2 in heart function and structure might depend on the species (Gurley et al. 2006). Interestingly, ACE2 expression has been reported to be increased in failing human heart ventricle (Zisman et al. 2003, Goulter et al. 2004, Burrell et al. 2005). Nevertheless, there are contrasting findings in rat hearts. While an increase of both ACE and ACE2 was found by Burrell et al. (2005) in hearts from Sprague-Dawley rats after myocardial infarction, Ishiyama et al. (2004) observed an increase in ACE2 expression only after $\mathrm{AT}_{1}$ blockade in Lewis normotensive rats. These divergent results further suggest that ACE2 effects are strain dependent. ACE2 gene transfection using lentiviral vectors significantly attenuated cardiac damage in SHR (Diez-Freire et al. 2006) and in Ang II-infused Sprague-Dawley rats (Huentelman et al. 2005). Also, the stage of the disease apparently influences the expression of ACE2. At the early phase of myocardial infarction, ACE2 activity in plasma and left ventricles is increased in rats while the plasma and left ventricular ACE2 activities and mRNA levels are lower than in controls at 8 weeks postinfarction (Ocaranza et al. 2006). Similar findings were observed regarding the cardiac expression of Mas, i.e. it changes depending on the nature

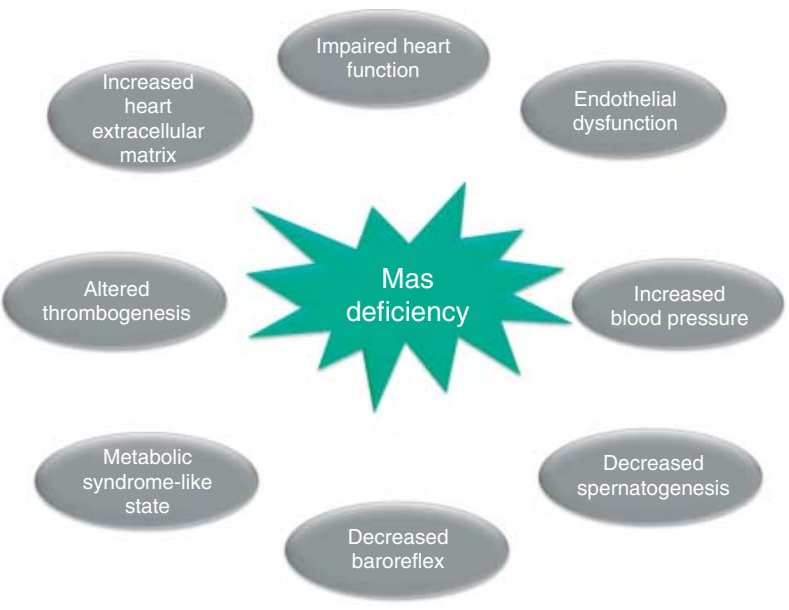

Figure 3

Phenotypic changes observed in mice with gene-targeted deletion of Mas.

Published by Bioscientifica Ltd 
and duration of the physiological and pathological stimuli (Dias-Peixoto et al. 2012).

The actions of Ang-(1-7) in coronary vessels include biochemical and functional alterations leading to vasodilatation either directly in artery rings or indirectly through bradykinin (BK) potentiation or by opposing Ang II actions (Santos et al. 2000). In isolated canine coronary artery rings precontracted with the thromboxane $A_{2}$ analog, U46619, Ang-(1-7) elicited a dosedependent vasorelaxation, which was completely blocked by the nonselective Ang II antagonist $\left[\mathrm{Sar}^{1}, \mathrm{Thr}^{8}\right]$-Ang II, but not by the selective $\mathrm{AT}_{1}$ or $\mathrm{AT}_{2}$ antagonists, CV11974 and PD 123319 respectively (Brosnihan et al. 1996). This heptapeptide induced a concentration-dependent dilator response in porcine coronary artery rings, which were markedly attenuated by nitric oxide (NO) inhibition (Porsti et al. 1994). However, Gorelik et al. (1998) observed a vasodilator effect of Ang-(1-7) only in BK-stimulated pig coronary artery rings. Furthermore, Ang-(1-7) elicited an increase in the vasodilator effect of BK in isolated perfused rat hearts. This effect was dependent on Mas and NO and prostaglandin release (Almeida et al. 2000). Ang-(1-7) also evoked vasodilation in isolated perfused mouse hearts involving interaction of Mas with $\mathrm{AT}_{1}$ - and $\mathrm{AT}_{2}$-related mechanisms (Castro et al. 2005). Together, these data suggest that Ang-(1-7) is a vasorelaxant peptide in the coronary bed and that this effect involves coupling to Mas and release of $\mathrm{NO}$ and prostaglandins. Nevertheless, because Neves et al. (1997) found that, at high concentrations (>25 nM), Ang-(1-7) induces a concentrationdependent decrease in coronary flow in isolated perfused rat hearts, it remains to be demonstrated whether Ang(1-7) directly causes vasodilation in the coronary bed. This effect was not accompanied by consistent changes in contraction force and heart rate. A similar finding was observed in isolated hamster hearts (Kumagai et al. 1990). Thus, low concentrations of Ang-(1-7) should be tested to clarify this important issue.

Recent reports have indicated that heart tissue is also an important target for ACE2/Ang-(1-7)/Mas actions. It has been demonstrated that Ang-(1-7) decreases the incidence and duration of ischemia-reperfusion arrhythmias in isolated perfused rat hearts (Ferreira et al. 2001) apparently involving activation of the sodium pump (De Mello 2004). These effects were abolished by ouabain (De Mello 2004). Additionally, Ang-(1-7) decreased total $\left(\mathrm{Na}^{+}, \mathrm{K}^{+}, \mathrm{Mg}^{2+}\right)$-ATPase activity in sheep atrium (Lopez Ordieres et al. 1998). Also, the antiarrhythmogenic effect of Ang-(1-7) was blocked by the Ang-(1-7) antagonist A-779 and by the cyclooxygenase (COX) inhibitor indomethacin (Ferreira et al. 2001). Importantly, it has been reported that all components of the ACE2/Ang-(17)/Mas axis are expressed in sinoatrial cells of rats, thereby providing morphological support to the antiarrhythmogenic effect of Ang-(1-7) (Ferreira et al. 2012). This peptide also improved postischemic contractile function in isolated heart preparations by a mechanism involving Mas and the release of BK and prostaglandins (Ferreira et al. 2002). However, at concentrations $\sim 10000$-fold higher, Neves et al. (1997) found that Ang-(1-7) facilitated reperfusion arrhythmias in isolated perfused rat hearts. In keeping with this latter data, transgenic mice overexpressing ACE2 in the heart presented sudden death due to cardiac arrhythmias (Donoghue et al. 2003). These observations suggest that only very high local concentrations of Ang-(1-7) exert deleterious effects in the heart possibly through activation of NADPH oxidase (Oudot et al. 2005) or release of norepinephrine (Gironacci et al. 1994). In fact, transgenic rats presenting a local increase of Ang-(1-7) of up to 20 -fold in the heart did not show any sign of arrhythmias (Ferreira et al. 2010).

Ang-(1-7) produced a significant increase in cardiac output and stroke volume in Wistar rats, partially attenuated by A-779 (Sampaio et al. 2003). These effects were also observed in transgenic rats that express a fusion protein capable of releasing Ang-(1-7) into circulating blood, increasing plasma concentration of this peptide 2.5-fold (Botelho-Santos et al. 2007). In addition, these animals showed a slight, but significant, increase in daily and nocturnal $\mathrm{dP} / \mathrm{dt}$, more resistance to isoproterenolinduced cardiac hypertrophy, reduced duration of reperfusion arrhythmias, and improved postischemic function in isolated perfused hearts (Santos et al. 2004), further supporting a beneficial role for Ang-(1-7) in cardiac function at physiological concentrations. According to Loot et al. (2002) chronic infusion (8 weeks) of Ang-(1-7) improved coronary perfusion and preserved cardiac function in an experimental rat model of heart failure induced by ligation of the left coronary artery. The vascular endothelial dysfunction observed in aortic rings from rats with myocardial infarction was also reversed by chronic infusion of Ang-(1-7) (Loot et al. 2002). In addition, Ang-(1-7) immunoreactivity was significantly increased in the tissue surrounding the infarct area of rat hearts with myocardial infarction (Averill et al. 2003).

Wiemer et al. (2002) published the first study demonstrating that the compound AVE 0991 is a nonpeptide and orally active Ang-(1-7) receptor agonist that mimics the Ang-(1-7) effects in bovine endothelial cells. Pinheiro et al. (2004) and Lemos et al. (2005) reported

Published by Bioscientifica Ltd. 
that this compound acts as a Mas agonist in the kidney and isolated aortic rings respectively. We have observed that AVE 0991 preserved cardiac function and attenuated the development of hypertrophy and fibrosis in hearts from rats chronically treated with isoproterenol (Ferreira et al. 2007b). This nonpeptide Ang-(1-7) analog also significantly improved the cardiac function in hearts subjected to myocardial infarction and preserved the myocardium after ischemia (Ferreira et al. 2007a). Furthermore, long-term treatment with AVE 0991 prevented the end-organ damage in hearts from spontaneously hypertensive rats treated with L-NAME (Benter et al. 2006).

Recently, it has been shown that the inclusion of Ang-(1-7) into the cavity formed by the oligosaccharide hydroxypropyl $\beta$-cyclodextrin (HP $\beta C D$ ) could protect the peptide during the passage through the gastrointestinal tract. Taking advantage of this formulation, Marques et al. (2011, 2012) found that chronic oral administration of HP $\beta C D /$ Ang-(1-7) significantly attenuated the impairment of heart function and cardiac remodeling induced by isoproterenol treatment and myocardial infarction in rats. Furthermore, CGEN-856S, a Mas agonist, promoted antiarrhythmic effects and produced a small dosedependent decrease in arterial pressure in conscious SHR (Savergnini et al. 2010). Interestingly, activation of intrinsic ACE2 using the compound XNT improved the cardiac function of spontaneously hypertensive rats (SHR; Hernandez Prada et al. 2008) and of diabetic rats (Murca et al. 2012a,b).

One of the most important beneficial effects of Ang-(1-7) is its ability to regulate the expression of extracellular matrix proteins and cardiac remodeling. Iwata et al. (2005) reported that Ang-(1-7) binds to isolated adult rat cardiac fibroblasts, which play a critical role in cardiac remodeling. Treatment of these cells with Ang(1-7) inhibited Ang II-induced increases in collagen synthesis. Ang-(1-7) also attenuated either fetal bovine serum- or endothelin 1-stimulated ${ }^{3} \mathrm{H}$-leucine incorporation into isolated neonatal rat cardiac myocytes through a mechanism involving inhibition of serum-stimulated ERK1/2 MAP kinase activity and activation of Mas (Tallant et al. 2005). Chronic administration of this peptide significantly attenuated left ventricular hypertrophy and fibrosis in pressure-overloaded rats (Wang et al. 2005) and fibrosis in Ang II-infused and deoxycorticosterone acetate (DOCA)-salt rats (Grobe et al. 2006, 2007). Importantly, deletion of Mas produced impairment of cardiac function associated with a significant increase in collagen type I, III and fibronectin content in the heart (Santos et al. 2006, Gava et al. 2012). On the other hand, ACE2 activation using XNT decreased cardiac fibrosis induced by high blood pressure through a mechanism involving reduction of ERK1/2 expression (Hernandez Prada et al. 2008, Ferreira et al. 2011). Altogether, these findings indicate that the ACE2/Ang-(1-7)/Mas axis is a functional cardioprotective arm of the RAS (Fig. 2).

The signal transduction pathways following activation of Mas in the heart are not fully characterized, but probably involve release of prostacyclin and/or NO release (Almeida et al. 2000, Ferreira et al. 2001, Castro et al. 2005) since Ang(1-7) stimulated NO production and activated endothelial NO synthase (eNOS) and Akt in cardiomyocytes (Dias-Peixoto et al. 2008). Of note, the antihypertrophic effects of Ang-(1-7) on Ang II-treated cardiomyocytes were prevented by the blockade of the NO/cGMP pathway (Gomes et al. 2010). Moreover, amplification of the actions of BK (Gorelik et al. 1998, Almeida et al. 2000) and decrease of Ang II levels in the heart (Mendes et al. 2005, Nadu et al. 2008) may also be possible mechanisms involved in the beneficial cardiac effects of Ang-(1-7).

\section{Vascular actions of the ACE2/Ang-(1-7)/Mas axis}

Blood vessels are an important site for the formation and actions of Ang-(1-7) (Santos et al. 2000, Santos \& Ferreira 2007). Endothelial cells are not only involved in the production but also in the metabolism of this heptapeptide (Velez et al. 2012). The ACE2/Ang-(1-7)/Mas axis induces the release of vasodilators, including prostanoids, $\mathrm{NO}$ and endothelium-derived hyperpolarizing factor (Porsti et al. 1994, Brosnihan et al. 1996, Li et al. 1997, Muthalif et al. 1998, Iyer et al. 2000, Fernandes et al. 2001, Heitsch et al. 2001). Accordingly, Ang-(1-7) elicits relaxation in several vascular beds (see Santos et al. (2000) for review). In line with these observations, activation of endogenous ACE2 provokes reductions in arterial blood pressure of normal and hypertensive rats (Hernandez Prada et al. 2008). However, contradictory effects of Ang-(1-7) have been reported in human vessels. While Sasaki et al. (2001) reported vasodilation in the human forearm, Davie \& McMurray (1999) did not observe any effect of Ang-(1-7) in the same territory in ACE inhibitor-treated patients.

Because plasma levels of Ang-(1-7) are increased during treatment with ACE inhibitors or $\mathrm{AT}_{1}$ receptor blockers part of their effects might be dependent on Ang-(1-7) (Ferrario 2006). Indeed a role for Ang-(1-7) in mediating the decrease in blood pressure produced by treatment with losartan in normal rats has been proposed (Collister \& Hendel 2003).

Published by Bioscientifica Ltd 
Several mechanisms are involved in the Ang-(1-7) vasodilatory effect, depending on the vessel diameter, the vascular regional bed, and the species. A complex interaction between Mas, $\mathrm{BK}_{2}, \mathrm{AT}_{1} \mathrm{R}$ and $\mathrm{AT}_{2} \mathrm{R}$ appears to be involved in mediating the Ang-(1-7) effects in some blood vessel preparations (Brosnihan et al. 1996, Gorelik et al. 1998, Soares de Moura et al. 2004).

Ang-(1-7) potentiates BK in several vascular beds and species. This BK-potentiating effect of Ang-(1-7) may contribute for its cardiovascular effects in normotensive (Paula et al. 1995, Oliveira et al. 1999, Greco et al. 2006) and hypertensive (Lima et al. 1997, Fernandes et al. 2001) rats. Several mechanisms have been proposed to explain the BK-potentiating activity of Ang-(1-7), including ACE inhibition since Ang-(1-7) is an ACE substrate (Li et al. 1997, Tom et al. 2001), allosteric changes in ACE (Erdos et al. 2002), and Mas-mediated changes in the BK signaling (Paula et al. 1995, Oliveira et al. 1999, Fernandes et al. 2001, Ferreira et al. 2001). In addition, vascular Ang-(1-7) actions could involve modulation of vascular effects of Ang II (Roks et al. 1999, Stegbauer et al. 2004).

Mas is involved in most of the known vascular effects of Ang-(1-7) and is present in human endothelial cells (Santos et al. 2005, Sampaio et al. 2007b). The endothelium-dependent relaxation induced by Ang-(1-7), AVE 0991 and CGEN-856S in mouse aortic rings is absent in vessels derived from Mas-deficient mice and is blocked by A-779 (Santos et al. 2003a, Lemos et al. 2005, Savergnini et al. 2010). A link between Mas and NO release was described by Pinheiro et al. (2004) and Sampaio et al. (2007b). Sampaio et al. (2007b) found that in both Mastransfected Chinese hamster ovary $(\mathrm{CHO})$ cells and human aortic endothelial cells (HAECs) Ang-(1-7) induces the release of NO through coordinated phosphorylation/dephosphorylation of eNOS. According to these authors, Ang-(1-7) induced phosphorylation of the stimulatory site Ser ${ }^{1777}$ and dephosphorylation of the inhibitory site $\mathrm{Thr}^{495}$ (Sampaio et al. 2007b). This effect could involve the activation of the PI3K-AKT pathway. The Mas antagonist A-779 blocked all the effects of Ang-(1-7) on eNOS in both cell types. These in vitro observations are in keeping with the effects of Ang-(1-7) on endothelial function in vivo (Faria-Silva et al. 2005).

\section{Renal actions of the ACE2/Ang-(1-7)/Mas axis}

A number of evidences substantially support the important role of ACE2/Ang-(1-7)/Mas axis in renal function. The renal concentration of Ang-(1-7) and Ang II is comparable (Joyner et al. 2007), and it is possible to detect
Ang-(1-7) in the human urine. Interestingly, untreated patients with essential hypertension present decreased amounts of Ang-(1-7) in the urine when compared with healthy volunteers (Ferrario et al. 1998). Moreover, the enzymes involved in the formation of Ang-(1-7) are abundant in the kidney (Erdos \& Skidgel 1990). By using mass spectrometry, Grobe et al. (2012) studied the distribution of the enzymatic machinery involved in Ang II metabolism within the mouse kidney. They reported that Ang-(1-7) and Ang-(1-4) were predominantly formed in the renal cortex, while Ang III was mainly produced in the renal medulla. The colocalization of Ang-(1-7) and Ang-(1-4) suggests that ACE2 and NEP are mainly found in the renal cortex. Indeed, in the kidney NEP plays a key role in the degradation of Ang-(1-7) to form its metabolite Ang-(1-4). Alike in the circulation, renal NEP also catalyzes the formation of Ang-(1-7) from Ang I or Ang-(1-9) (Allred et al. 2000, Chappell et al. 2001, Dilauro \& Burns 2009, Pinheiro \& Simoes 2012). In another recent study, which investigated the localization of the renal RAS components by immunohistochemistry, ACE2 was predominantly found along the proximal nephron (Pohl et al. 2010). Moreover, ACE2 was reported to be 20 -fold more active in the mouse renal cortex than in cardiac tissue (Wysocki et al. 2006). Although most of the studies reported that ACE2 is predominantly expressed in the renal cortex, there are still some controversies regarding its localization since i) semiquantitative RT-PCR analysis revealed that ACE2 mRNA is found in all nephron segments - including the medulla with the exception of the medullary thick ascending limb of Henle's loop (mTAL); and ii) ACE2 protein was detected by western blot and immunohistochemistry in the outer medulla and inner medulla, besides the renal cortex (Li et al. 2005).

Recently, Pohl et al. (2010) studied the ability of the scavenger receptor megalin to modulate the expression of ACE and ACE2 in the brush border membrane of the proximal tubule. The authors observed that megalindeficient mice had a higher immunofluorescence staining for ACE2 when compared with megalin-positive cell populations. By contrast, ACE staining was weaker in brush border membranes of megalin-deficient proximal tubular cells. This result suggests that megalin itself or megalin-related pathways regulate the expression of both isoforms in proximal tubular cells.

Mas seems to have a broad localization in the kidney. Alenina et al. (2008) reported that Mas mRNA is predominantly found in the renal cortex of male mice. Indeed, functional Mas is detected in proximal tubules,

Published by Bioscientifica Ltd 
as well as in the afferent arterioles, collecting ducts and the thick ascending limb of Henle and its expression is upregulated in renal ischemia (Ren et al. 2002, Gwathmey et al. 2010, Silveira et al. 2010, Zimmerman $\&$ Burns 2012).

Ang-(1-7) is known to induce an antiproliferative and protective effect by counterregulating the MAP kinase signaling induced by Ang II via $\mathrm{AT}_{1}$ receptors (Sampaio et al. 2007a). Interestingly, Liu et al. (2012) recently reported that Ang-(1-7) induced ERK1/2 activation in glomerular mesangial cells via Mas. However, the authors demonstrated that, diverging from Ang II that induces ERK1/2 activation via NADPH oxidase activation or epidermal growth factor receptor (EGFR) transactivation, Ang-(1-7)/Mas leads to ERK1/2 phosphorylation in a cAMP/PKA-dependent manner (Liu et al. 2012), suggesting that, in these cells, Mas is coupled to Gsa. Rakusan et al. (2010) found that Mas deletion exacerbated renal hypertension in mice that was reversed with tempol or apocynin again suggesting a role in oxidative stress.

The Ang-(1-7) effects in the kidney are quite complex and controversial. A diuretic/natriuretic action of Ang-(1-7) due to inhibition of sodium reabsorption at the proximal tubule was proposed. In this context, Ang-(1-7) seems to limit transcellular sodium flux by modulating the activity of transporters via phospholipase A2 activation in tubular epithelial cells (Andreatta-van Leyen et al. 1993). Moreover, this heptapeptide appears to be a potent inhibitor of $\mathrm{Na}^{+}-\mathrm{K}^{+}$-ATPase activity in the renal cortex and in isolated convoluted proximal tubules (Handa et al. 1996, Lopez Ordieres et al. 1998, Burgelova et al. 2002, De Souza et al. 2004, Dilauro \& Burns 2009, Pinheiro \& Simoes 2012). This inhibitory effect is reversed by the $\mathrm{AT}_{2}$ receptor antagonist PD 123319 in a dose-dependent manner in the inner cortex basolateral membrane from pig kidney. Interestingly, neither A-779 nor losartan affected this process, indicating that the inhibition of the $\mathrm{Na}^{+}-\mathrm{K}^{+}$-ATPase activity by Ang-(1-7) is mediated by $\mathrm{AT}_{2}$ or another $\mathrm{PD}$ 123319-sensitive mechanism (De Souza et al. 2004). In vitro studies indicated that Ang-(1-7) reverses the stimulatory effect of Ang II on the $\mathrm{Na}^{+}$-ATPase activity in proximal tubule via Mas (Burgelova et al. 2002).

In contrast to that, an antidiuretic/antinatriuretic effect of Ang-(1-7) was observed in water-loaded rats (for review, see Joyner et al. (2008), Dilauro \& Burns (2009) and Pinheiro \& Simoes (2012)) and this effect seems to be at least partially mediated by Mas activation since A-779 blocks the Ang-(1-7) antidiuretic effect (Santos et al. 1996). Simoes e Silva et al. (1998) reported that chronic administration of A-779 in both normotensive and SHR rats leads to natriuresis and diuresis. In addition, A-779 treatment in virgin female rats leads to increased urinary volume and decreased osmolality with no changes in water intake (Joyner et al. 2008). On the other hand, the Mas agonist AVE 0991 significantly reduced urinary volume (Pinheiro et al. 2004). All these data suggest that the diuretic/natriuretic effect observed in water-loaded animals are induced by the Mas activation. However, it is important to point out that other Ang receptors than Mas (e.g. $\mathrm{AT}_{1}$ and $\mathrm{AT}_{2}$ ) could also be involved in this process. A study on tubular bicarbonate transport implicated the $\mathrm{AT}_{1}$ receptor in a biphasic response to Ang-(1-7) (Garcia \& Garvin 1994).

The above-mentioned discrepancies between the Ang-(1-7) actions in the kidney may be explained by differences in experimental design (for example, in vitro vs in vivo), animal model (e.g. conscious vs anesthetized animals), Ang-(1-7) concentration, nephron segment, species, level of RAS activity, and water and salt status. Moreover, Ang-(1-7) can induce opposite effects in different physiological situations of an animal. For example in pregnant rats, Ang-(1-7) induces diuresis associated with downregulation of aquaporin-1 while in virgin females this heptapeptide leads to antidiuresis and upregulation of aquaporin-1 (Joyner et al. 2008). It is evident that the renal RAS depicts an intricate regulatory mechanism far more complex than expected. Nonetheless, further studies need to clarify the mechanisms underlying the renal actions of Ang-(1-7).

Besides its physiological relevance for kidney homeostasis, the ACE2/Ang-(1-7)/Mas axis also has an important and controversial role in renal diseases, acting as a renoprotective (Oudit et al. 2006, 2010, Soler et al. 2007, Pinheiro et al. 2009, Burns et al. 2010, Dilauro et al. 2010, Zhang et al. 2010, Giani et al. 2011, 2012, Liu et al. 2011b, Moon et al. 2011, Stegbauer et al. 2011, Zhong et al. 2011, Barroso et al. 2012, Kim et al. 2012, Nadarajah et al. 2012, Zhou et al. 2012) or a proinflammatory (Esteban et al. 2009, Velkoska et al. 2011) agent. Briefly, Pinheiro et al. (2009) reported that mice with genetic deletion of Mas developed renal dysfunction with an increase of glomerular tuft diameter and enhancement of fibronectin and collagen IV and III deposition, besides an increase of $\mathrm{AT}_{1}$ and TGF- $\beta$ expression. Moreover, Ang-(1-7) infusion counterregulates Ang II to reduce glomerulosclerosis in experimental glomerulonephritis (Zhang et al. 2010). In addition, chronic inhibition of ACE2 with MLN-4760

Published by Bioscientifica Ltd 
in both healthy and diabetic mice led to glomerular injury and albuminuria (Soler et al. 2007). It is important to highlight that the ACE levels were notably increased in this study (Soler et al. 2007). Moreover, ACE2 was downregulated in the cortex of mice subjected to subtotal nephrectomy (Dilauro et al. 2010). Administration of recombinant ACE2 diminished fibrosis, i.e. glomerular mesangial matrix, smooth muscle actin and collagen III expression in diabetic AKITA mice (Oudit et al. 2010) and in wild-type mice infused with Ang II (Zhong et al. 2011). Accordingly, knockout mice for ACE2 infused with Ang II showed enhanced collagen I deposition and expression of genes related to fibrosis, such as smooth muscle actin, TGF-beta, and procollagen I, probably through activation of ERK1/2 and enhancement of protein kinase C levels (Zhong et al. 2011). Taken together, these data suggest that renal pathogenesis is driven by a disruption in the ACE-ACE2 balance. Nonetheless, there are some studies suggesting a deleterious role for the renal ACE2/Ang-(1-7)/Mas axis that are conflicting with the above-mentioned studies. For example, Esteban et al. found that Mas knockout mice presented an attenuation of renal damage in a renal insufficiency model. The authors reported that Ang-(1-7) infusion led to NF- $\mathrm{KB}$ activation and inflammation via Mas (Esteban et al. 2009). Tikellis et al. described that ACE2 knockout mice exhibit an increased albuminuria in a streptozotocin-induced diabetes model, but at the same time an attenuated expression of marker genes for diabetic nephropathy. Moreover, Velkoska et al. (2011) reported that Ang-(1-7) treatment of male SpragueDawley rats after subtotal nephrectomy induced deleterious cardiovascular effects as well as increasing levels of fibrosis when compared with controls. By contrast, no aggravation of renal injury produced by kidney ischemia-reperfusion was observed in $\mathrm{Mas}^{-1-}$ mice, and in the same model the Mas agonist AVE 0991 reduced renal injury (Barroso et al. 2012). Ang-(1-7) was also reported to stimulate (Burns et al. 2010) or to inhibit (Zhou et al. 2012) the epithelial-to-mesenchymal transformation in tubular cells.

These conflicting findings are probably due to differences in the models used and to cell-specific Ang-(1-7) signaling in the kidney, for example the dependency of each model on COX-2-mediated events, which can be differentially modulated by Ang-(1-7) (Albrecht 2007, Menon et al. 2007), and highlight the need for further in vivo studies related to the RAS and its novel axis in kidney disease.

\section{Metabolic actions of the ACE2/Ang-(1-7)/Mas axis}

The existence of local RAS has already been reported in the endocrine and exocrine pancreas (Chappell et al. 1991, Leung et al. 1997, 1999), as well as in the adipose tissue (Schling et al. 1999). The components of these local RAS are highly regulated by food intake. High sugar diet increased the expression levels of angiotensinogen, ACE and $\mathrm{AT}_{1}$ in pancreas (Lupi et al. 2006). Similarly, a diet rich in fat or sugar increased the concentration of ACE2 and Ang-(1-7) in adipose tissue (Gupte et al. 2008, Coelho et al. 2010). Therefore, the RAS is considered a potential target for treating the metabolic syndrome, which is characterized by obesity, insulin resistance, hypertension, dyslipidemia, and other symptoms (Grundy et al. 2004).

The observation that insulin resistance is frequently associated with cardiovascular impairments suggests interplay between the RAS and insulin. Such a relationship was prompted by clinical trials (Hansson et al. 1999, Brenner et al. 2001, Yusuf et al. 2001, Dahlof et al. 2002) and experimental studies (Oliveira et al. 2002, Furuhashi et al. 2004, Lupi et al. 2006) where the overall observation was an improvement in hyperglycemia by inhibiting the RAS either with $\mathrm{ACE}$ inhibitors or $\mathrm{AT}_{1}$ antagonists. Moreover, it has already been shown that the upregulation of ACE2 also improves hyperglycemia in diabetic rats (Bindom et al. 2010). Therefore, it is clear that, together with BK, Ang-(1-7) has an important antihyperglycemic effect while Ang II acts in the opposite way. Indeed, many studies have reported that Ang-(1-7) attenuates the manifestations of the metabolic syndrome, increases glucose uptake and protects cells against the oxidative stress that can induce insulin resistance (Santos et al. 2008, Giani et al. 2009, Liu et al. 2011a).

The molecular mechanisms underlying the positive regulation of insulin promoted by Ang-(1-7) are now being revealed. It has been reported that Ang-(1-7) and insulin have some common downstream signaling effectors in HAEC (Sampaio et al. 2007b) and in the hearts (Giani et al. 2007). Ang-(1-7) induces the phosphorylation of the insulin downstream effectors PI3K and AKT via Mas in HAEC (Giani et al. 2007, Sampaio et al. 2007b) and IRS-1 and JAK2 via $\mathrm{AT}_{1}$ receptor in hearts (Giani et al. 2007). Moreover, Ang-(1-7)/Mas negatively regulates Ang II/AT ${ }_{1}$ signaling in HAEC by promoting dephosphorylation of c-Src and ERK1/2 and inhibition of NADPH oxidase activity (Sampaio et al. 2007a). Recently, our group used a phosphoproteome approach to study Ang-(1-7) signaling in human endothelial cells. This study revealed novel downstream components of Ang-(1-7)/Mas signaling and

Published by Bioscientifica Ltd 
provided additional evidence for an interplay between insulin and Ang-(1-7) networks (Verano-Braga et al. 2012).

Lipid metabolism is also regulated by Ang-(1-7). Mas knockout mice on $\mathrm{FVB} / \mathrm{N}$ background had impairments in lipid metabolism, leading to dyslipidemia, lower glucose tolerance and insulin sensitivity, hyperinsulinemia, hyperleptinemia, lower adiponectin secretion, decreased glucose uptake and increased abdominal fat mass when compared with the wild-type phenotype (Santos et al. 2008). On the other hand, despite the normal food intake, TGR(A1-7)3292 animals with increased plasmatic levels of Ang-(1-7) showed reduced fat mass and decreased triglycerides and cholesterol levels. In addition to that, the expression levels of adiponectin and adipose lipidbinding protein (AP2) were increased while there was a remarkable decrease in the angiotensinogen expression in these animals. Adiponectin is a key adipokine that regulates insulin sensitivity and tissue inflammation and its plasmatic level is inversely proportional to body fat content, and AP2 is an important protein in adipose tissue metabolism involved in fatty acid esterification (Santos et al. 2010). In the same way, ACE knockout mice presented reduced fat mass due to an increased lipid metabolism and energy expenditure as a consequence of higher expression levels of key genes involved in the hydrolysis of lipids into free fatty acids (lipoprotein lipase (LPL)), translocation of fatty acids to the mitochondria (carnitine palmitoyltransferase 1 (CPT-1)), and $\beta$-oxidation inside mitochondria and peroxisomes (long-chain acyl-CoA dehydrogenase (LCAD); Jayasooriya et al. 2008).

Thus, considering that comparable results were obtained using different animal models and technical approaches, we believe that there is enough evidence proving a key role of the ACE2/Ang-(1-7)/Mas axis in the regulation of carbohydrate and lipid metabolism.

\section{Ang-(1-7) as an $\mathrm{AT}_{1}$ receptor antagonist}

Mahon et al. (1994) described that Ang-(1-7) can antagonize the pressor effect of Ang II in anesthetized rats. This was achieved with very high doses of Ang-(1-7). Lately, Rowe et al. (1995) reported that Ang-(1-7) binds to $\mathrm{AT}_{1}$ receptors. Again, this was observed at high concentrations of Ang-(1-7) ( $\left.\geq 10^{-6} \mathrm{~mol} / \mathrm{l}\right)$. However, Gironacci et al. (1999) reported that Ang-(1-7) may compete for the binding of $\mathrm{AT}_{1}$ receptors with high affinity $\left(K_{\mathrm{i}}=8 \cdot 0 \pm 3 \cdot 2 \mathrm{nM}\right)$ in kidney slices. Moreover, Ang-(1-7), which was without effect on basal $\left[\mathrm{Ca}^{2+}\right]_{\mathrm{i}}$, reduced Ang II- and Ang IV-dependent $\left[\mathrm{Ca}^{2+}\right]_{\mathrm{i}}$ increases in mesangial cells (Chansel et al. 2001). In common, most of these studies used pharmacological concentrations of Ang-(1-7), suggesting that, in this condition, Ang-(1-7) could compete for $\mathrm{AT}_{1}$ receptors (Oudot et al. 2005).

At physiological concentrations, Ang-(1-7) is an endogenous modulator of the $\mathrm{AT}_{1}$-mediated Ang II responses. This phenomenon is clearly observed at the intracellular level. Ang-(1-7) antagonized the Ang IIinduced activation of protein kinase $C$ and ERK1/2 in vascular smooth muscle cells (VSMCs; Zhu et al. 2002). This peptide also significantly attenuated the Ang IIinduced reactive oxygen species generation, c-Src and ERK1/2 activation, and stimulated SHP-2 in CHO cells transfected with Mas and in HAEC (Sampaio et al. 2007a). Tallant \& Clark (2003) demonstrated that Ang-(1-7) inhibits Ang II stimulation of ERK1/2 in cultured rat aortic VSMCs through a prostacyclin-mediated production of cAMP and activation of cAMP-dependent protein kinase. In addition, Ang II-induced ERK1/2 phosphorylation was also inhibited by Ang-(1-7) in rat cardiomyocytes. This effect was abolished by transfection of cells with an antisense oligonucleotide to Mas (Tallant et al. 2005). In proximal tubular cells, Ang II-stimulated phosphorylation of three MAP kinases (p38, ERK1/2 and c-Jun) was also inhibited by Ang-(1-7), an effect that was also completely blocked by the Mas antagonist A-779 (Su et al. 2006). Furthermore, a Mas-dependent inhibition of Ang IIinduced EGFR transactivation by Ang-(1-7) has also been demonstrated in rat VSMCs (Akhtar et al. 2012).

Additionally, it could be possible that Ang-(1-7) modulates Ang II effects at the molecular level during $\mathrm{AT}_{1}$ mRNA synthesis and/or translation. Actually, $\mathrm{AT}_{1}$ receptor expression appears to be downregulated in $\mathrm{CHO}$ cells stably transfected with the $\mathrm{AT}_{1 \mathrm{a}}$ receptor pretreated with 1 or $10 \mu \mathrm{M}$ Ang-(1-7) (Clark et al. 2001b). This effect was also observed in rat aortic VSMCs (Clark et al. 2001a) and in the cortical tubulointerstitial area of the kidney (Clark et al. 2003). However, Neves et al. (2000) have found that Ang-(1-7) upregulates the mRNA expression of the $\mathrm{AT}_{1}$ receptor in VSMCs. A similar upregulation was reported by Canals et al. (2006) in cells overexpressing Mas.

Several studies have also described a direct physical interaction with a possible antagonistic effect between Mas and the $\mathrm{AT}_{1}$ receptor (Kostenis et al. 2005, Santos et al. 2007). Future studies are obviously necessary to clarify the nature of the interaction between both receptors.

\section{Ang-(1-7) and the $A T_{2}$ receptor}

Ang-(1-7) has a very low affinity for $\mathrm{AT}_{2}$ receptors (Rowe et al. 1995). Indeed, many of the Ang-(1-7) effects were not

Published by Bioscientifica Ltd 
influenced by $\mathrm{AT}_{2}$ receptor antagonists (Brosnihan et al. 1996, Santos et al. 2000, Tallant et al. 2005, Dharmani et al. 2007, Silva et al. 2007). However, in certain circumstances and in some tissues $\mathrm{AT}_{2}$ receptors appear to be involved in Ang-(1-7) actions. For instance, in isolated mouse hearts treated with the $\mathrm{AT}_{2}$ antagonist PD 123319, Ang-(1-7) produced an increase in the perfusion pressure that could not be attributed to interaction with $\mathrm{AT}_{1}$ or Mas receptors (Castro et al. 2005). In this preparation, blockade of $\mathrm{AT}_{1}$ receptors unmasked a vasodilator effect of Ang(1-7) at a subpicomolar concentration, which was Mas dependent. Another intriguing observation was reported by Walters et al. (2005) in candesartan-treated SHR. In these animals, Ang-(1-7) produced a substantial decrease in blood pressure, which was not modified by the Ang-(1-7) receptor antagonist A-779 but was fully blocked by the $\mathrm{AT}_{2}$ antagonist PD 123319. There are few other reports in which an effect of Ang-(1-7) was blocked or attenuated by PD 123319 but not by A-779 (De Souza et al. 2004, Lara et al. 2006, Pereyra-Alfonso et al. 2007).

In sharp contrast with these observations are several studies describing a complete or, less frequently, partial inhibition of Ang-(1-7) effects with A-779 (Santos et al. 2000, Ferreira et al. 2001, Santos et al. 2005, Ferrario 2006, Gallagher et al. 2006). In some studies a partial blockade was obtained with the $\mathrm{AT}_{2}$ antagonist PD 123319 when a partial inhibition was also seen with A-779 and the $\mathrm{B}_{2}$ receptor antagonist Hoe 140. Likewise, some BK effects are attenuated by PD 123319 (Bergaya et al. 2004) and some $\mathrm{AT}_{2}$-mediated effects are attenuated by $\mathrm{B}_{2}$ receptor blockade (Munk et al. 2007). These observations illustrate the intricate relationship between Ang and kinin receptors, suggesting intracellular interactions via common signaling pathways or heterodimerization. The mechanisms of such interaction are currently only elusive. However, physical interactions between Mas and $\mathrm{AT}_{2}$ or $\mathrm{B}_{2}$ receptors in selected tissues should be considered as explanation for some of the puzzling observations with the use of receptor antagonists.

\section{Concluding remarks}

The complexity of the RAS is far beyond what we could suspect few years ago. New elements have recently been added to the system (ACE2, Ang-(1-7), Mas, (Pro)renin receptor) (Ferreira \& Santos 2005, Ferrario 2006, Santos \& Ferreira 2007, Sihn et al. 2010) and have completely changed its perception. It is now generally accepted that the RAS is dual and that, besides the well known mainly deleterious arm (ACE/Ang II/AT 1 ), there is a second beneficial axis consisting of ACE2, Ang-(1-7), and Mas. The evidence summarized in this review clearly shows a participation of this new RAS axis in the regulation of blood pressure and metabolism, and, even more importantly, in the pathogenesis of, at least, cardiovascular, renal, and metabolic diseases. Therefore, the novel concept of the dual RAS is invigorating the development of new cardiovascular drugs activating the beneficial arm of the RAS (Ferreira et al. 2012).

\section{Declaration of interest}

The authors declare that there is no conflict of interest that could be perceived as prejudicing the impartiality of the research reported.

\section{Funding}

This work was supported by CAPES/DAAD (PROBRAL).

\section{References}

Akhtar S, Yousif MH, Dhaunsi GS, Chandrasekhar B, Al-Farsi O \& Benter IF 2012 Angiotensin-(1-7) inhibits epidermal growth factor receptor transactivation via a Mas receptor-dependent pathway. British Journal of Pharmacology 165 1390-1400. (doi:10.1111/j.1476-5381.2011.01613.x)

Albrecht D 2007 Angiotensin-(1-7)-induced plasticity changes in the lateral amygdala are mediated by COX-2 and NO. Learning \& Memory 14 177-184. (doi:10.1101/lm.425907)

Alenina N, Xu P, Rentzsch B, Patkin EL \& Bader M 2008 Genetically altered animal models for Mas and angiotensin-(1-7). Experimental Physiology 93 528-537. (doi:10.1113/expphysiol.2007.040345)

Allred AJ, Chappell MC, Ferrario CM \& Diz DI 2000 Differential actions of renal ischemic injury on the intrarenal angiotensin system. American Journal of Physiology. Renal Physiology 279 F636-F645. (doi:10.1590/ S0100-879X2000000600012)

Almeida AP, Frabregas BC, Madureira MM, Santos RJ, Campagnole-Santos MJ $\&$ Santos RA 2000 Angiotensin-(1-7) potentiates the coronary vasodilatatory effect of bradykinin in the isolated rat heart. Brazilian Journal of Medical and Biological Research 33 709-713.

Ambuhl P, Felix D \& Khosla MC 1994 [7-D-ALA]-angiotensin-(1-7): selective antagonism of angiotensin-(1-7) in the rat paraventricular nucleus. Brain Research Bulletin 35 289-291. (doi:10.1016/03619230(94)90103-1)

Andreatta-van Leyen S, Romero MF, Khosla MC \& Douglas JG 1993 Modulation of phospholipase A2 activity and sodium transport by angiotensin-(1-7). Kidney International 44 932-936. (doi:10.1038/ki. 1993.334)

Averill DB, Ishiyama Y, Chappell MC \& Ferrario CM 2003 Cardiac angiotensin-(1-7) in ischemic cardiomyopathy. Circulation 108 2141-2146. (doi:10.1161/01.CIR.0000092888.63239.54)

Bader M 2010 Tissue renin-angiotensin-aldosterone systems: targets for pharmacological therapy. Annual Review of Pharmacology and Toxicology 50 439-465. (doi:10.1146/annurev.pharmtox.010909.105610)

Barroso LC, Silveira KD, Lima CX, Borges V, Bader M, Rachid M, Santos RA, Souza DG, Simoes ESAC \& Teixeira MM 2012 Renoprotective effects of AVE0991, a nonpeptide Mas receptor agonist, in experimental acute renal injury. International Journal of Hypertension 2012808726. (doi:10.1155/2012/808726)

Benter IF, Yousif MH, Anim JT, Cojocel C \& Diz DI 2006 Angiotensin-(1-7) prevents development of severe hypertension and end-organ damage 
in spontaneously hypertensive rats treated with L-NAME. American Journal of Physiology. Heart and Circulatory Physiology 290 H684-H691. (doi:10.1152/ajpheart.00632.2005)

Bergaya S, Hilgers RH, Meneton P, Dong Y, Bloch-Faure M, Inagami T, Alhenc-Gelas F, Levy BI \& Boulanger CM 2004 Flow-dependent dilation mediated by endogenous kinins requires angiotensin $\mathrm{AT}_{2}$ receptors. Circulation Research 94 1623-1629. (doi:10.1161/01.RES.0000131497. 73744.1a)

Bindom SM, Hans CP, Xia H, Boulares AH \& Lazartigues E 2010 Angiotensin I-converting enzyme type 2 (ACE2) gene therapy improves glycemic control in diabetic mice. Diabetes 59 2540-2548. (doi:10. 2337/db09-0782)

Botelho-Santos GA, Sampaio WO, Reudelhuber TL, Bader M, Campagnole-Santos MJ \& Souza dos Santos RA 2007 Expression of an angiotensin-(1-7)-producing fusion protein in rats induced marked changes in regional vascular resistance. American Journal of Physiology. Heart and Circulatory Physiology 292 H2485-H2490. (doi:10.1152/ ajpheart.01245.2006)

Brenner BM, Cooper ME, de Zeeuw D, Keane WF, Mitch WE, Parving HH, Remuzzi G, Snapinn SM, Zhang Z \& Shahinfar S 2001 Effects of losartan on renal and cardiovascular outcomes in patients with type 2 diabetes and nephropathy. New England Journal of Medicine 345 861-869. (doi:10.1056/NEJMoa011161)

Brosnihan KB, Li P \& Ferrario CM 1996 Angiotensin-(1-7) dilates canine coronary arteries through kinins and nitric oxide. Hypertension $\mathbf{2 7}$ 523-528. (doi:10.1161/01.HYP.27.3.523)

Burgelova M, Kramer HJ, Teplan V, Velickova G, Vitko S, Heller J, Maly J \& Cervenka L 2002 Intrarenal infusion of angiotensin-(1-7) modulates renal functional responses to exogenous angiotensin II in the rat. Kidney \& Blood Pressure Research 25 202-210. (doi:10.1159/000066340)

Burns WC, Velkoska E, Dean R, Burrell LM \& Thomas MC 2010 Angiotensin II mediates epithelial-to-mesenchymal transformation in tubular cells by ANG 1-7/MAS-1-dependent pathways. American Journal of Physiology. Renal Physiology 299 F585-F593. (doi:10.1152/ ajprenal.00538.2009)

Burrell LM, Risvanis J, Kubota E, Dean RG, MacDonald PS, Lu S, Tikellis C, Grant SL, Lew RA, Smith AI et al. 2005 Myocardial infarction increases ACE2 expression in rat and humans. European Heart Journal 26 369-375; (discussion 322-364). (doi:10.1093/eurheartj/ehi114)

Campagnole-Santos MJ, Diz DI, Santos RA, Khosla MC, Brosnihan KB \& Ferrario CM 1989 Cardiovascular effects of angiotensin-(1-7) injected into the dorsal medulla of rats. American Journal of Physiology $\mathbf{2 5 7}$ H324-H329.

Campagnole-Santos MJ, Heringer SB, Batista EN, Khosla MC \& Santos RA 1992 Differential baroreceptor reflex modulation by centrally infused angiotensin peptides. American Journal of Physiology 263 R89-R94.

Campbell DJ, Zeitz CJ, Esler MD \& Horowitz JD 2004 Evidence against a major role for angiotensin converting enzyme-related carboxypeptidase (ACE2) in angiotensin peptide metabolism in the human coronary circulation. Journal of Hypertension 22 1971-1976. (doi:10.1097/00004872-200410000-00020)

Canals M, Jenkins L, Kellett E \& Milligan G 2006 Up-regulation of the angiotensin II type 1 receptor by the MAS proto-oncogene is due to constitutive activation of Gq/G11 by MAS. Journal of Biological Chemistry 281 16757-16767. (doi:10.1074/jbc.M601121200)

Carey RM \& Siragy HM 2003 Newly recognized components of the renin-angiotensin system: potential roles in cardiovascular and renal regulation. Endocrine Reviews 24 261-271. (doi:10.1210/er.2003-0001)

Castro CH, Santos RA, Ferreira AJ, Bader M, Alenina N \& Almeida AP 2005 Evidence for a functional interaction of the angiotensin-(1-7) receptor Mas with $\mathrm{AT}_{1}$ and $\mathrm{AT}_{2}$ receptors in the mouse heart. Hypertension 46 937-942. (doi:10.1161/01.HYP.0000175813.04375.8a)

Chansel D, Vandermeersch S, Oko A, Curat C \& Ardaillou R 2001 Effects of angiotensin IV and angiotensin-(1-7) on basal and angiotensin II-stimulated cytosolic $\mathrm{Ca}^{2+}$ in mesangial cells. European

http://joe.endocrinology-journals.org DOI: $10.1530 / J O E-12-0341$
() 2013 Society for Endocrinology Printed in Great Britain
Journal of Pharmacology 414 165-175. (doi:10.1016/S0014-2999(01) 00791-9)

Chappell MC, Brosnihan KB, Diz DI \& Ferrario CM 1989 Identification of angiotensin-(1-7) in rat brain. Evidence for differential processing of angiotensin peptides. Journal of Biological Chemistry 264 16518-16523.

Chappell MC, Milsted A, Diz DI, Brosnihan KB \& Ferrario CM 1991 Evidence for an intrinsic angiotensin system in the canine pancreas. Journal of Hypertension 9 751-759. (doi:10.1097/00004872-19910800000008)

Chappell MC, Pirro NT, Sykes A \& Ferrario CM 1998 Metabolism of angiotensin-(1-7) by angiotensin-converting enzyme. Hypertension $\mathbf{3 1}$ 362-367. (doi:10.1161/01.HYP.31.1.362)

Chappell MC, Gomez MN, Pirro NT \& Ferrario CM 2000 Release of angiotensin-(1-7) from the rat hindlimb: influence of angiotensinconverting enzyme inhibition. Hypertension 35 348-352. (doi:10.1161/ 01.HYP.35.1.348)

Chappell MC, Allred AJ \& Ferrario CM 2001 Pathways of angiotensin-(1-7) metabolism in the kidney. Nephrology, Dialysis, Transplantation 16(Suppl 1) 22-26. (doi:10.1093/ndt/16.suppl_1.22)

Clark MA, Diz DI \& Tallant EA 2001a Angiotensin-(1-7) downregulates the angiotensin II type 1 receptor in vascular smooth muscle cells. Hypertension 37 1141-1146. (doi:10.1161/01.HYP.37.4.1141)

Clark MA, Tallant EA \& Diz DI $2001 b$ Downregulation of the $\mathrm{AT}_{1} \mathrm{~A}$ receptor by pharmacologic concentrations of angiotensin-(1-7). Journal of Cardiovascular Pharmacology 37 437-448. (doi:10.1097/00005344200104000-00011)

Clark MA, Tallant EA, Tommasi E, Bosch S \& Diz DI 2003 Angiotensin-(1-7) reduces renal angiotensin II receptors through a cyclooxygenasedependent mechanism. Journal of Cardiovascular Pharmacology $\mathbf{4 1}$ 276-283. (doi:10.1097/00005344-200302000-00017)

Coelho MS, Lopes KL, Freitas Rde A, de Oliveira-Sales EB, Bergasmaschi CT, Campos RR, Casarini DE, Carmona AK, Araujo Mda S, Heimann JC et al. 2010 High sucrose intake in rats is associated with increased ACE2 and angiotensin-(1-7) levels in the adipose tissue. Regulatory Peptides 162 61-67. (doi:10.1016/j.regpep.2010.03.008)

Collister JP \& Hendel MD 2003 The role of Ang (1-7) in mediating the chronic hypotensive effects of losartan in normal rats. Journal of ReninAngiotensin-Aldosterone System 4 176-179. (doi:10.3317/jraas.2003.028)

Crackower MA, Sarao R, Oudit GY, Yagil C, Kozieradzki I, Scanga SE, Oliveira-dos-Santos AJ, da Costa J, Zhang L, Pei Y et al. 2002 Angiotensin-converting enzyme 2 is an essential regulator of heart function. Nature 417 822-828. (doi:10.1038/nature00786)

Dahlof B, Devereux RB, Kjeldsen SE, Julius S, Beevers G, de Faire U, Fyhrquist F, Ibsen H, Kristiansson K, Lederballe-Pedersen O et al. 2002 Cardiovascular morbidity and mortality in the Losartan Intervention For Endpoint reduction in hypertension study (LIFE): a randomised trial against atenolol. Lancet 359 995-1003. (doi:10.1016/S01406736(02)08089-3)

Davie AP \& McMurray JJ 1999 Effect of angiotensin-(1-7) and bradykinin in patients with heart failure treated with an ACE inhibitor. Hypertension 34 457-460. (doi:10.1161/01.HYP.34.3.457)

De Mello WC 2004 Angiotensin (1-7) re-establishes impulse conduction in cardiac muscle during ischaemia-reperfusion. The role of the sodium pump. Journal of Renin-Angiotensin-Aldosterone System 5 203-208. (doi:10.3317/jraas.2004.041)

De Souza AM, Lopes AG, Pizzino CP, Fossari RN, Miguel NC, Cardozo FP, Abi-Abib R, Fernandes MS, Santos DP \& Caruso-Neves C 2004 Angiotensin II and angiotensin-(1-7) inhibit the inner cortex $\mathrm{Na}^{+}$ATPase activity through $\mathrm{AT}_{2}$ receptor. Regulatory Peptides 120 167-175. (doi:10.1016/j.regpep.2004.03.005)

Dharmani M, Mustafa MR, Achike FI \& Sim MK 2007 Effects of angiotensin 1-7 on the actions of angiotensin II in the renal and mesenteric vasculature of hypertensive and streptozotocin-induced diabetic rats. European Journal of Pharmacology 561 144-150. (doi:10.1016/j.ejphar. 2007.01.037) 
Dias-Peixoto MF, Santos RA, Gomes ER, Alves MN, Almeida PW, Greco L, Rosa M, Fauler B, Bader M, Alenina N et al. 2008 Molecular mechanisms involved in the angiotensin-(1-7)/Mas signaling pathway in cardiomyocytes. Hypertension 52 542-548. (doi:10.1161/HYPERTENSIONAHA.108.114280)

Dias-Peixoto MF, Ferreira AJ, Almeida PW, Braga VB, Coutinho DC, Melo DS, Gomes Filho A, Melo MB, Greco L, Campagnole-Santos MJ et al. 2012 The cardiac expression of Mas receptor is responsive to different physiological and pathological stimuli. Peptides 35 196-201. (doi:10.1016/j.peptides.2012.03.022)

Diez-Freire C, Vazquez J, Correa de Adjounian MF, Ferrari MF, Yuan L, Silver X, Torres R \& Raizada MK 2006 ACE2 gene transfer attenuates hypertension-linked pathophysiological changes in the SHR. Physiological Genomics 27 12-19. (doi:10.1152/physiolgenomics.00312. 2005)

Dilauro M \& Burns KD 2009 Angiotensin-(1-7) and its effects in the kidney. Scientific World Journal 9 522-535. (doi:10.1100/tsw.2009.70)

Dilauro M, Zimpelmann J, Robertson SJ, Genest D \& Burns KD 2010 Effect of ACE2 and angiotensin-(1-7) in a mouse model of early chronic kidney disease. American Journal of Physiology. Renal Physiology 298 F1523-F1532. (doi:10.1152/ajprenal.00426.2009)

Donoghue M, Hsieh F, Baronas E, Godbout K, Gosselin M, Stagliano N Donovan M, Woolf B, Robison K, Jeyaseelan R et al. 2000 A novel angiotensin-converting enzyme-related carboxypeptidase (ACE2) converts angiotensin I to angiotensin 1-9. Circulation Research 87 E1-E9. (doi:10.1161/01.RES.87.5.e1)

Donoghue M, Wakimoto H, Maguire CT, Acton S, Hales P, Stagliano N, Fairchild-Huntress V, Xu J, Lorenz JN, Kadambi V et al. 2003 Heart block, ventricular tachycardia, and sudden death in ACE2 transgenic mice with downregulated connexins. Journal of Molecular and Cellular Cardiology 35 1043-1053. (doi:10.1016/S0022-2828(03)00177-9)

Dostal DE \& Baker KM 1999 The cardiac renin-angiotensin system: conceptual, or a regulator of cardiac function? Circulation Research $\mathbf{8 5}$ 643-650. (doi:10.1161/01.RES.85.7.643)

Erdos EG \& Skidgel RA 1990 Renal metabolism of angiotensin I and II. Kidney International. Supplement 30 S24-S27.

Erdos EG, Jackman HL, Brovkovych V, Tan F \& Deddish PA 2002 Products of angiotensin I hydrolysis by human cardiac enzymes potentiate bradykinin. Journal of Molecular and Cellular Cardiology 34 1569-1576. (doi:10.1006/jmcc.2002.2080)

Esteban V, Heringer-Walther S, Sterner-Kock A, de Bruin R, van den Engel S, Wang Y, Mezzano S, Egido J, Schultheiss HP, Ruiz-Ortega M et al. 2009 Angiotensin-(1-7) and the g protein-coupled receptor MAS are key players in renal inflammation. PLoS ONE 4 e5406. (doi:10.1371/ journal.pone.0005406)

Faria-Silva R, Duarte FV \& Santos RA 2005 Short-term angiotensin(1-7) receptor MAS stimulation improves endothelial function in normotensive rats. Hypertension 46 948-952. (doi:10.1161/01.HYP. 0000174594.17052.33)

Fernandes L, Fortes ZB, Nigro D, Tostes RC, Santos RA \& Catelli De Carvalho MH 2001 Potentiation of bradykinin by angiotensin-(1-7) on arterioles of spontaneously hypertensive rats studied in vivo. Hypertension 37 703-709. (doi:10.1161/01.HYP. 37.2.703)

Ferrario CM 2006 Angiotensin-converting enzyme 2 and angiotensin(1-7): an evolving story in cardiovascular regulation. Hypertension 47 515-521. (doi:10.1161/01.HYP.0000196268.08909.fb)

Ferrario CM, Martell N, Yunis C, Flack JM, Chappell MC, Brosnihan KB, Dean RH, Fernandez A, Novikov SV, Pinillas C et al. 1998 Characterization of angiotensin-(1-7) in the urine of normal and essential hypertensive subjects. American Journal of Hypertension 11 137-146. (doi:10.1016/S0895-7061(97)00400-7)

Ferreira AJ \& Santos RA 2005 Cardiovascular actions of angiotensin-(1-7). Brazilian Journal of Medical and Biological Research 38 499-507. (doi:10.1590/S0100-879X2005000400003)
Ferreira AJ, Santos RA \& Almeida AP 2001 Angiotensin-(1-7): cardioprotective effect in myocardial ischemia/reperfusion. Hypertension $\mathbf{3 8}$ 665-668. (doi:10.1161/01.HYP.38.3.665)

Ferreira AJ, Santos RA \& Almeida AP 2002 Angiotensin-(1-7) improves the post-ischemic function in isolated perfused rat hearts. Brazilian Journal of Medical and Biological Research 35 1083-1090. (doi:10.1590/ S0100-879X2002000900009)

Ferreira AJ, Jacoby BA, Araujo CA, Macedo FA, Silva GA, Almeida AP, Caliari MV \& Santos RA 2007a The nonpeptide angiotensin-(1-7) receptor Mas agonist AVE-0991 attenuates heart failure induced by myocardial infarction. American Journal of Physiology. Heart and Circulatory Physiology 292 H1113-H1119. (doi:10.1152/ajpheart.00828. 2006)

Ferreira AJ, Oliveira TL, Castro MC, Almeida AP, Castro CH, Caliari MV, Gava E, Kitten GT \& Santos RA 2007b Isoproterenol-induced impairment of heart function and remodeling are attenuated by the nonpeptide angiotensin-(1-7) analogue AVE 0991. Life Sciences $\mathbf{8 1}$ 916-923. (doi:10.1016/j.lfs.2007.07.022)

Ferreira AJ, Castro CH, Guatimosim S, Almeida PW, Gomes ER, Dias-Peixoto MF, Alves MN, Fagundes-Moura CR, Rentzsch B, Gava E et al. 2010 Attenuation of isoproterenol-induced cardiac fibrosis in transgenic rats harboring an angiotensin-(1-7)-producing fusion protein in the heart. Therapeutic Advances in Cardiovascular Disease 4 83-96. (doi:10.1177/1753944709353426)

Ferreira AJ, Shenoy V, Qi Y, Fraga-Silva RA, Santos RA, Katovich MJ \& Raizada MK 2011 Angiotensin-converting enzyme 2 activation protects against hypertension-induced cardiac fibrosis involving extracellular signal-regulated kinases. Experimental Physiology 96 287-294. (doi:10.1113/expphysiol.2010.055277)

Ferreira AJ, Bader M \& Santos RA 2012 Therapeutic targeting of the angiotensin-converting enzyme 2/Angiotensin-(1-7)/Mas cascade in the renin-angiotensin system: a patent review. Expert Opinion on Therapeutic Patents 22 567-574. (doi:10.1517/13543776.2012.682572)

Fraga-Silva RA, Pinheiro SV, Goncalves AC, Alenina N, Bader M \& Santos RA 2008 The antithrombotic effect of angiotensin-(1-7) involves mas-mediated NO release from platelets. Molecular Medicine 14 28-35. (doi:10.2119/2007-00073.Fraga-Silva)

Furuhashi M, Ura N, Takizawa H, Yoshida D, Moniwa N, Murakami H, Higashiura K \& Shimamoto K 2004 Blockade of the renin-angiotensin system decreases adipocyte size with improvement in insulin sensitivity. Journal of Hypertension 22 1977-1982. (doi:10.1097/00004872200410000-00021)

Gallagher PE, Chappell MC, Ferrario CM \& Tallant EA 2006 Distinct roles for ANG II and ANG-(1-7) in the regulation of angiotensin-converting enzyme 2 in rat astrocytes. American Journal of Physiology. Cell Physiology 290 C420-C426. (doi:10.1152/ajpcell.00409.2004)

Garabelli PJ, Modrall JG, Penninger JM, Ferrario CM \& Chappell MC 2008 Distinct roles for angiotensin-converting enzyme 2 and carboxypeptidase A in the processing of angiotensins within the murine heart. Experimental Physiology 93 613-621. (doi:10.1113/expphysiol.2007. 040246)

Garcia NH \& Garvin JL 1994 Angiotensin 1-7 has a biphasic effect on fluid absorption in the proximal straight tubule. Journal of the American Society of Nephrology 5 1133-1138.

Gava E, de Castro CH, Ferreira AJ, Colleta H, Melo MB, Alenina N, Bader M, Oliveira LA, Santos RA \& Kitten GT 2012 Angiotensin-(1-7) receptor Mas is an essential modulator of extracellular matrix protein expression in the heart. Regulatory Peptides 175 30-42. (doi:10.1016/j.regpep.2012. 01.001)

Giani JF, Gironacci MM, Munoz MC, Pena C, Turyn D \& Dominici FP 2007 Angiotensin-(1 7) stimulates the phosphorylation of JAK2, IRS-1 and Akt in rat heart in vivo: role of the $\mathrm{AT}_{1}$ and Mas receptors. American Journal of Physiology. Heart and Circulatory Physiology 293 H1154-H1163. (doi:10.1152/ajpheart.01395.2006)

Giani JF, Mayer MA, Munoz MC, Silberman EA, Hocht C, Taira CA, Gironacci MM, Turyn D \& Dominici FP 2009 Chronic infusion of 
angiotensin-(1-7) improves insulin resistance and hypertension induced by a high-fructose diet in rats. American Journal of Physiology. Endocrinology and Metabolism 296 E262-E271. (doi:10.1152/ajpendo. 90678.2008)

Giani JF, Munoz MC, Pons RA, Cao G, Toblli JE, Turyn D \& Dominici FP 2011 Angiotensin-(1-7) reduces proteinuria and diminishes structural damage in renal tissue of stroke-prone spontaneously hypertensive rats. American Journal of Physiology. Renal Physiology 300 F272-F282. (doi:10.1152/ajprenal.00278.2010)

Giani JF, Burghi V, Veiras LC, Tomat A, Munoz MC, Cao G, Turyn D, Toblli JE \& Dominici FP 2012 Angiotensin-(1-7) attenuates diabetic nephropathy in Zucker diabetic fatty rats. American Journal of Physiology. Renal Physiology 302 F1606-F1615. (doi:10.1152/ajprenal. 00063.2012)

Gironacci MM, Adler-Graschinsky E, Pena C \& Enero MA 1994 Effects of angiotensin II and angiotensin-(1-7) on the release of $\left[{ }^{3} \mathrm{H}\right]$ norepinephrine from rat atria. Hypertension 24 457-460. (doi:10.1161/ 01.HYP.24.4.457)

Gironacci MM, Coba MP \& Pena C 1999 Angiotensin-(1-7) binds at the type 1 angiotensin II receptors in rat renal cortex. Regulatory Peptides $\mathbf{8 4}$ 51-54. (doi:10.1016/S0167-0115(99)00067-1)

Gomes ER, Lara AA, Almeida PW, Guimaraes D, Resende RR, CampagnoleSantos MJ, Bader M, Santos RA \& Guatimosim S 2010 Angiotensin-(1-7) prevents cardiomyocyte pathological remodeling through a nitric oxide/guanosine $3^{\prime}, 5^{\prime}$-cyclic monophosphate-dependent pathway. Hypertension 55 153-160. (doi:10.1161/HYPERTENSIONAHA.109. 143255)

Gorelik G, Carbini LA \& Scicli AG 1998 Angiotensin 1-7 induces bradykinin-mediated relaxation in porcine coronary artery. Journal of Pharmacology and Experimental Therapeutics 286 403-410.

Goulter AB, Goddard MJ, Allen JC \& Clark KL 2004 ACE2 gene expression is up-regulated in the human failing heart. BMC Medicine 219. (doi:10.1186/1741-7015-2-19)

Greco AJ, Master RG, Fokin A Jr, Baber SR \& Kadowitz PJ 2006 Angiotensin(1-7) potentiates responses to bradykinin but does not change responses to angiotensin I. Canadian Journal of Physiology and Pharmacology 84 1163-1175. (doi:10.1139/y06-053)

Grinstead WC \& Young JB 1992 The myocardial renin-angiotensin system: existence, importance, and clinical implications. American Heart Journal 123 1039-1045. (doi:10.1016/0002-8703(92)90715-8)

Grobe JL, Mecca AP, Mao H \& Katovich MJ 2006 Chronic angiotensin-(1-7) prevents cardiac fibrosis in DOCA-salt model of hypertension. American Journal of Physiology. Heart and Circulatory Physiology 290 H2417-H2423. (doi:10.1152/ajpheart.01170.2005)

Grobe JL, Mecca AP, Lingis M, Shenoy V, Bolton TA, Machado JM, Speth RC, Raizada MK \& Katovich MJ 2007 Prevention of angiotensin II-induced cardiac remodeling by angiotensin-(1-7). American Journal of Physiology. Heart and Circulatory Physiology 292 H736-H742. (doi:10.1152/ajpheart. 00937.2006)

Grobe N, Elased KM, Cool DR \& Morris M 2012 Mass spectrometry for the molecular imaging of angiotensin metabolism in kidney. American Journal of Physiology. Endocrinology and Metabolism 302 E1016-E1024. (doi:10.1152/ajpendo.00515.2011)

Grundy SM, Brewer HB Jr, Cleeman JI, Smith SC Jr \& Lenfant C 2004 Definition of metabolic syndrome: Report of the National Heart, Lung, and Blood Institute/American Heart Association conference on scientific issues related to definition. Circulation $109433-438$. (doi:10.1161/01.CIR.0000111245.75752.C6)

Gupte M, Boustany-Kari CM, Bharadwaj K, Police S, Thatcher S, Gong MC, English VL \& Cassis LA 2008 ACE2 is expressed in mouse adipocytes and regulated by a high-fat diet. American Journal of Physiology. Regulatory, Integrative and Comparative Physiology 295 R781-R788. (doi:10.1152/ajpregu.00183.2008)

Gurley SB, Allred A, Le TH, Griffiths R, Mao L, Philip N, Haystead TA, Donoghue M, Breitbart RE, Acton SL et al. 2006 Altered blood pressure responses and normal cardiac phenotype in ACE2-null mice. Journal of Clinical Investigation 116 2218-2225. (doi:10.1172/JCI16980)

Gwathmey TM, Westwood BM, Pirro NT, Tang L, Rose JC, Diz DI \& Chappell MC 2010 Nuclear angiotensin-(1-7) receptor is functionally coupled to the formation of nitric oxide. American Journal of Physiology. Renal Physiology 299 F983-F990. (doi:10.1152/ajprenal.00371.2010)

Handa RK, Ferrario CM \& Strandhoy JW 1996 Renal actions of angiotensin(1-7): in vivo and in vitro studies. American Journal of Physiology 270 F141-F147.

Hansson L, Lindholm LH, Niskanen L, Lanke J, Hedner T, Niklason A, Luomanmaki K, Dahlof B, de Faire U, Morlin C et al. 1999 Effect of angiotensin-converting-enzyme inhibition compared with conventional therapy on cardiovascular morbidity and mortality in hypertension: the Captopril Prevention Project (CAPPP) randomised trial. Lancet 353 611-616. (doi:10.1016/S0140-6736(98)05012-0)

Harmer D, Gilbert M, Borman R \& Clark KL 2002 Quantitative mRNA expression profiling of ACE 2, a novel homologue of angiotensin converting enzyme. FEBS Letters 532 107-110. (doi:10.1016/S00145793(02)03640-2)

Heitsch H, Brovkovych S, Malinski T \& Wiemer G 2001 Angiotensin-(1-7)stimulated nitric oxide and superoxide release from endothelial cells. Hypertension 37 72-76. (doi:10.1161/01.HYP.37.1.72)

Hernandez Prada JA, Ferreira AJ, Katovich MJ, Shenoy V, Qi Y, Santos RA, Castellano RK, Lampkins AJ, Gubala V, Ostrov DA et al. 2008 Structurebased identification of small-molecule angiotensin-converting enzyme 2 activators as novel antihypertensive agents. Hypertension $\mathbf{5 1}$ 1312-1317. (doi:10.1161/HYPERTENSIONAHA.107.108944)

Huentelman MJ, Grobe JL, Vazquez J, Stewart JM, Mecca AP, Katovich MJ, Ferrario CM \& Raizada MK 2005 Protection from angiotensin IIinduced cardiac hypertrophy and fibrosis by systemic lentiviral delivery of ACE2 in rats. Experimental Physiology 90 783-790. (doi:10.1113/ expphysiol.2005.031096)

Ishiyama Y, Gallagher PE, Averill DB, Tallant EA, Brosnihan KB \& Ferrario CM 2004 Upregulation of angiotensin-converting enzyme 2 after myocardial infarction by blockade of angiotensin II receptors. Hypertension 43 970-976. (doi:10.1161/01.HYP.0000124667.34652.1a)

Iwata M, Cowling RT, Gurantz D, Moore C, Zhang S, Yuan JX \& Greenberg BH 2005 Angiotensin-(1-7) binds to specific receptors on cardiac fibroblasts to initiate antifibrotic and antitrophic effects. American Journal of Physiology. Heart and Circulatory Physiology 289 H2356-H2363. (doi:10.1152/ajpheart.00317.2005)

Iyer SN, Yamada K, Diz DI, Ferrario CM \& Chappell MC 2000 Evidence that prostaglandins mediate the antihypertensive actions of angiotensin(1-7) during chronic blockade of the renin-angiotensin system. Journal of Cardiovascular Pharmacology 36 109-117. (doi:10.1097/ 00005344-200007000-00015)

Jayasooriya AP, Mathai ML, Walker LL, Begg DP, Denton DA, Cameron-Smith D, Egan GF, McKinley MJ, Rodger PD, Sinclair AJ et al. 2008 Mice lacking angiotensin-converting enzyme have increased energy expenditure, with reduced fat mass and improved glucose clearance. PNAS 105 6531-6536. (doi:10.1073/pnas.0802690105)

Jin HY, Song B, Oudit GY, Davidge ST, Yu HM, Jiang YY, Gao PJ, Zhu DL, Ning G, Kassiri Z et al. 2012 ACE2 deficiency enhances angiotensin IImediated aortic profilin-1 expression, inflammation and peroxynitrite production. PLOS ONE 7 e38502. (doi:10.1371/journal.pone.0038502)

Joyner J, Neves LA, Granger JP, Alexander BT, Merrill DC, Chappell MC, Ferrario CM, Davis WP \& Brosnihan KB 2007 Temporal-spatial expression of ANG-(1-7) and angiotensin-converting enzyme 2 in the kidney of normal and hypertensive pregnant rats. American Journal of Physiology. Regulatory, Integrative and Comparative Physiology 293 R169-R177. (doi:10.1152/ajpregu.00387.2006)

Joyner J, Neves LA, Stovall K, Ferrario CM \& Brosnihan KB 2008 Angiotensin-(1-7) serves as an aquaretic by increasing water intake and diuresis in association with downregulation of aquaporin-1 during pregnancy in rats. American Journal of Physiology. Regulatory, Integrative 
and Comparative Physiology 294 R1073-R1080. (doi:10.1152/ajpregu. 00572.2007)

Kim SM, Kim YG, Jeong KH, Lee SH, Lee TW, Ihm CG \& Moon JY 2012 Angiotensin II-induced mitochondrial Nox4 is a major endogenous source of oxidative stress in kidney tubular cells. PLOS ONE 7 e39739. (doi:10.1371/journal.pone.0039739)

Kostenis E, Milligan G, Christopoulos A, Sanchez-Ferrer CF, HeringerWalther S, Sexton PM, Gembardt F, Kellett E, Martini L, Vanderheyden P et al. 2005 G-protein-coupled receptor Mas is a physiological antagonist of the angiotensin II type 1 receptor. Circulation 111 1806-1813. (doi:10.1161/01.CIR.0000160867.23556.7D)

Kumagai H, Khosla M, Ferrario C \& Fouad-Tarazi FM 1990 Biological activity of angiotensin-(1-7) heptapeptide in the hamster heart. Hypertension 15 I29-I33. (doi:10.1161/01.HYP.15.2_Suppl.I29)

Lara Lda S, Cavalcante F, Axelband F, De Souza AM, Lopes AG \& Caruso-Neves C 2006 Involvement of the Gi/o/cGMP/PKG pathway in the $\mathrm{AT}_{2}$-mediated inhibition of outer cortex proximal tubule $\mathrm{Na}^{+}$-ATPase by Ang-(1-7). Biochemical Journal 395 183-190. (doi:10.1042/BJ20051455)

Lemos VS, Silva DM, Walther T, Alenina N, Bader M \& Santos RA 2005 The endothelium-dependent vasodilator effect of the nonpeptide Ang(1-7) mimic AVE 0991 is abolished in the aorta of mas-knockout mice. Journal of Cardiovascular Pharmacology 46 274-279. (doi:10.1097/01.fjc. 0000175237.41573.63)

Leung PS, Chan HC, Fu LX \& Wong PY 1997 Localization of angiotensin II receptor subtypes $\mathrm{AT}_{1}$ and $\mathrm{AT}_{2}$ in the pancreas of rodents. Journal of Endocrinology 153 269-274. (doi:10.1677/joe.0.1530269)

Leung PS, Chan WP, Wong TP \& Sernia C 1999 Expression and localization of the renin-angiotensin system in the rat pancreas. Journal of Endocrinology 160 13-19. (doi:10.1677/joe.0.1600013)

Li P, Chappell MC, Ferrario CM \& Brosnihan KB 1997 Angiotensin-(1-7) augments bradykinin-induced vasodilation by competing with ACE and releasing nitric oxide. Hypertension 29 394-400. (doi:10.1161/01. HYP. 29.1.394)

Li N, Zimpelmann J, Cheng K, Wilkins JA \& Burns KD 2005 The role of angiotensin converting enzyme 2 in the generation of angiotensin 1-7 by rat proximal tubules. American Journal of Physiology. Renal Physiology 288 F353-F362. (doi:10.1152/ajprenal.00144.2004)

Lima CV, Paula RD, Resende FL, Khosla MC \& Santos RA 1997 Potentiation of the hypotensive effect of bradykinin by short-term infusion of angiotensin-(1-7) in normotensive and hypertensive rats. Hypertension 30 542-548. (doi:10.1161/01.HYP.30.3.542)

Liu C, Lv XH, Li HX, Cao X, Zhang F, Wang L, Yu M \& Yang JK $2011 a$ Angiotensin-(1-7) suppresses oxidative stress and improves glucose uptake via Mas receptor in adipocytes. Acta Diabetologia 49 291-299. (doi:10.1007/s00592-011-0348-z)

Liu CX, Hu Q, Wang Y, Zhang W, Ma ZY, Feng JB, Wang R, Wang XP, Dong B, Gao F et al. 2011b Angiotensin-converting enzyme (ACE) 2 overexpression ameliorates glomerular injury in a rat model of diabetic nephropathy: a comparison with ACE inhibition. Molecular Medicine $\mathbf{1 7}$ 59-69. (doi:10.1007/s00894-010-0699-3)

Liu GC, Oudit GY, Fang F, Zhou J \& Scholey JW 2012 Angiotensin-(1-7)induced activation of ERK1/2 is cAMP/protein kinase A-dependent in glomerular mesangial cells. American Journal of Physiology. Renal Physiology 302 F784-F790. (doi:10.1152/ajprenal.00455.2011)

Loot AE, Roks AJ, Henning RH, Tio RA, Suurmeijer AJ, Boomsma F \& van Gilst WH 2002 Angiotensin-(1-7) attenuates the development of heart failure after myocardial infarction in rats. Circulation $\mathbf{1 0 5}$ 1548-1550. (doi:10.1161/01.CIR.0000013847.07035.B9)

Lopez Ordieres MG, Gironacci M, Rodriguez de Lores Arnaiz G \& Pena C 1998 Effect of angiotensin-(1-7) on ATPase activities in several tissues. Regulatory Peptides 77 135-139. (doi:10.1016/S0167-0115(98)00113-X)

Lupi R, Del Guerra S, Bugliani M, Boggi U, Mosca F, Torri S, Del Prato S \& Marchetti P 2006 The direct effects of the angiotensin-converting enzyme inhibitors, zofenoprilat and enalaprilat, on isolated human pancreatic islets. European Journal of Endocrinology 154 355-361. (doi:10.1530/eje.1.02086)

Mahmood A, Jackman HL, Teplitz L \& Igic R 2002 Metabolism of angiotensin I in the coronary circulation of normal and diabetic rats. Peptides 23 1171-1175. (doi:10.1016/S0196-9781(02)00051-7)

Mahon JM, Carr RD, Nicol AK \& Henderson IW 1994 Angiotensin(1-7) is an antagonist at the type 1 angiotensin II receptor. Journal of Hypertension 12 1377-1381. (doi:10.1097/00004872-199412000-00010)

Marques FD, Ferreira AJ, Sinisterra RD, Jacoby BA, Sousa FB, Caliari MV, Silva GA, Melo MB, Nadu AP, Souza LE et al. 2011 An oral formulation of angiotensin-(1-7) produces cardioprotective effects in infarcted and isoproterenol-treated rats. Hypertension 57 477-483. (doi:10.1161/ HYPERTENSIONAHA.110.167346)

Marques FD, Melo MB, Souza LE, Irigoyen MC, Sinisterra RD, de Sousa FB, Savergnini SQ, Braga VB, Ferreira AJ \& Santos RA 2012 Beneficial effects of long-term administration of an oral formulation of angiotensin(1-7) in infarcted rats. International Journal of Hypertension 2012 795452. (doi:10.1155/2012/795452)

Mendes AC, Ferreira AJ, Pinheiro SV \& Santos RA 2005 Chronic infusion of angiotensin-(1-7) reduces heart angiotensin II levels in rats. Regulatory Peptides 125 29-34. (doi:10.1016/j.regpep.2004.07.023)

Menon J, Soto-Pantoja DR, Callahan MF, Cline JM, Ferrario CM, Tallant EA \& Gallagher PE 2007 Angiotensin-(1-7) inhibits growth of human lung adenocarcinoma xenografts in nude mice through a reduction in cyclooxygenase-2. Cancer Research 67 2809-2815. (doi:10.1158/00085472.CAN-06-3614)

Metzger R, Bader M, Ludwig T, Berberich C, Bunnemann B \& Ganten D 1995 Expression of the mouse and rat mas proto-oncogene in the brain and peripheral tissues. FEBS Letters 357 27-32. (doi:10.1016/00145793(94)01292-9)

Moon JY, Tanimoto M, Gohda T, Hagiwara S, Yamazaki T, Ohara I, Murakoshi M, Aoki T, Ishikawa Y, Lee SH et al. 2011 Attenuating effect of angiotensin-(1-7) on angiotensin II-mediated NAD(P)H oxidase activation in type 2 diabetic nephropathy of KK-A(y)/Ta mice. American Journal of Physiology. Renal Physiology 300 F1271-F1282. (doi:10.1152/ ajprenal.00065.2010)

de Moura MM, dos Santos RA, Campagnole-Santos MJ, Todiras M, Bader M, Alenina N \& Haibara AS 2010 Altered cardiovascular reflexes responses in conscious angiotensin-(1-7) receptor Mas-knockout mice. Peptides 31 1934-1939. (doi:10.1016/j.peptides.2010.06.030)

Munk VC, Sanchez de Miguel L, Petrimpol M, Butz N, Banfi A, Eriksson U, Hein L, Humar R \& Battegay EJ 2007 Angiotensin II induces angiogenesis in the hypoxic adult mouse heart in vitro through an $\mathrm{AT}_{2}$-B2 receptor pathway. Hypertension 49 1178-1185. (doi:10.1161/ HYPERTENSIONAHA.106.080242)

Murca TM, Almeida TC, Raizada MK \& Ferreira AJ 2012a Chronic activation of endogenous angiotensin-converting enzyme 2 protects diabetic rats from cardiovascular autonomic dysfunction. Experimental Physiology $\mathbf{9 7}$ 699-709. (doi:10.1113/expphysiol.2011.063461)

Murca TM, Moraes PL, Capuruco CA, Santos SH, Melo MB, Santos RA, Shenoy V, Katovich MJ, Raizada MK \& Ferreira AJ 2012b Oral administration of an angiotensin-converting enzyme 2 activator ameliorates diabetes-induced cardiac dysfunction. Regulatory Peptides 177 107-115. (doi:10.1016/j.regpep.2012.05.093)

Muthalif MM, Benter IF, Uddin MR, Harper JL \& Malik KU 1998 Signal transduction mechanisms involved in angiotensin-(1-7)-stimulated arachidonic acid release and prostanoid synthesis in rabbit aortic smooth muscle cells. Journal of Pharmacology and Experimental Therapeutics 284 388-398.

Nadarajah R, Milagres R, Dilauro M, Gutsol A, Xiao F, Zimpelmann J, Kennedy C, Wysocki J, Batlle D \& Burns KD 2012 Podocyte-specific overexpression of human angiotensin-converting enzyme 2 attenuates diabetic nephropathy in mice. Kidney International 82 292-303. (doi:10.1038/ki.2012.83)

Nadu AP, Ferreira AJ, Reudelhuber TL, Bader M \& Santos RA 2008 Reduced isoproterenol-induced renin-angiotensin changes and 
extracellular matrix deposition in hearts of TGR(A1-7)3292 rats. Journal of the American Society of Hypertension 2 341-348. (doi:10.1016/ j.jash.2008.04.012)

Neves LA, Almeida AP, Khosla MC \& Santos RA 1995 Metabolism of angiotensin I in isolated rat hearts. Effect of angiotensin converting enzyme inhibitors. Biochemical Pharmacology 50 1451-1459. (doi:10.1016/0006-2952(95)02049-7)

Neves LA, Almeida AP, Khosla MC, Campagnole-Santos MJ \& Santos RA 1997 Effect of angiotensin-(1-7) on reperfusion arrhythmias in isolated rat hearts. Brazilian Journal of Medical and Biological Research 30 801-809. (doi:10.1590/S0100-879X1997000600016)

Neves LA, Santos RA, Khosla MC \& Milsted A 2000 Angiotensin-(1-7) regulates the levels of angiotensin II receptor subtype $\mathrm{AT}_{1}$ mRNA differentially in a strain-specific fashion. Regulatory Peptides 95 99-107. (doi:10.1016/S0167-0115(00)00164-6)

Ocaranza MP, Godoy I, Jalil JE, Varas M, Collantes P, Pinto M, Roman M, Ramirez C, Copaja M, Diaz-Araya G et al. 2006 Enalapril attenuates downregulation of angiotensin-converting enzyme 2 in the late phase of ventricular dysfunction in myocardial infarcted rat. Hypertension $\mathbf{4 8}$ 572-578. (doi:10.1161/01.HYP.0000237862.94083.45)

Oliveira MA, Fortes ZB, Santos RA, Kosla MC \& De Carvalho MH 1999 Synergistic effect of angiotensin-(1-7) on bradykinin arteriolar dilation in vivo. Peptides 20 1195-1201. (doi:10.1016/S0196-9781(99)00123-0)

Oliveira MA, Carvalho MH, Nigro D, Passaglia Rde C \& Fortes ZB 2002 Angiotensin-(1-7) and bradykinin interaction in diabetes mellitus: in vivo study. Peptides 23 1449-1455. (doi:10.1016/S0196-9781(02)00080-3)

Oudit GY, Herzenberg AM, Kassiri Z, Wong D, Reich H, Khokha R, Crackower MA, Backx PH, Penninger JM \& Scholey JW 2006 Loss of angiotensin-converting enzyme-2 leads to the late development of angiotensin II-dependent glomerulosclerosis. American Journal of Pathology 168 1808-1820. (doi:10.2353/ajpath.2006.051091)

Oudit GY, Liu GC, Zhong J, Basu R, Chow FL, Zhou J, Loibner H, Janzek E, Schuster M, Penninger JM et al. 2010 Human recombinant ACE2 reduces the progression of diabetic nephropathy. Diabetes 59 529-538. (doi:10.2337/db09-1218)

Oudot A, Vergely C, Ecarnot-Laubriet A \& Rochette L 2005 Pharmacological concentration of angiotensin-(1-7) activates NADPH oxidase after ischemia-reperfusion in rat heart through $\mathrm{AT}_{1}$ receptor stimulation. Regulatory Peptides 127 101-110. (doi:10.1016/j.regpep.2004.10.013)

Paula RD, Lima CV, Khosla MC \& Santos RA 1995 Angiotensin-(1-7) potentiates the hypotensive effect of bradykinin in conscious rats. Hypertension 26 1154-1159. (doi:10.1161/01.HYP.26.6.1154)

Pereyra-Alfonso S, Rodriguez de Lores Arnaiz G \& Pena C 2007 Phosphoinositide hydrolysis increase by angiotensin-(1-7) in neonatal rat brain. Regulatory Peptides 140 162-167. (doi:10.1016/j.regpep.2006. 12.005)

Pinheiro SV \& Simoes ESAC 2012 Angiotensin converting enzyme 2, angiotensin-(1-7), and receptor MAS axis in the kidney. International Journal of Hypertension 2012 414128. (doi:10.1155/2012/414128)

Pinheiro SV, Simoes e Silva AC, Sampaio WO, de Paula RD, Mendes EP Bontempo ED, Pesquero JB, Walther T, Alenina N, Bader M et al. 2004 Nonpeptide AVE 0991 is an angiotensin-(1-7) receptor Mas agonist in the mouse kidney. Hypertension 44 490-496. (doi:10.1161/01.HYP. 0000141438.64887.42)

Pinheiro SV, Ferreira AJ, Kitten GT, da Silveira KD, da Silva DA, Santos SH, Gava E, Castro CH, Magalhaes JA, da Mota RK et al. 2009 Genetic deletion of the angiotensin-(1-7) receptor Mas leads to glomerular hyperfiltration and microalbuminuria. Kidney International $\mathbf{7 5}$ 1184-1193. (doi:10.1038/ki.2009.61)

Pohl M, Kaminski H, Castrop H, Bader M, Himmerkus N, Bleich M, Bachmann S \& Theilig F 2010 Intrarenal renin angiotensin system revisited: role of megalin-dependent endocytosis along the proximal nephron. Journal of Biological Chemistry 285 41935-41946. (doi:10.1074/jbc.M110.150284)

Porsti I, Bara AT, Busse R \& Hecker M 1994 Release of nitric oxide by angiotensin-(1-7) from porcine coronary endothelium: implications for a novel angiotensin receptor. British Journal of Pharmacology 111 652-654. (doi:10.1111/j.1476-5381.1994.tb14787.x)

Rakusan D, Burgelova M, Vaneckova I, Vanourkova Z, Huskova Z, Skaroupkova P, Mrazova I, Opocensky M, Kramer HJ, Netuka I et al. 2010 Knockout of angiotensin 1-7 receptor Mas worsens the course of two-kidney, one-clip goldblatt hypertension: roles of nitric oxide deficiency and enhanced vascular responsiveness to angiotensin II. Kidney \& Blood Pressure Research 33 476-488. (doi:10.1159/000320689)

Ren Y, Garvin JL \& Carretero OA 2002 Vasodilator action of angiotensin(1-7) on isolated rabbit afferent arterioles. Hypertension 39 799-802. (doi:10.1161/hy0302.104673)

Rice GI, Thomas DA, Grant PJ, Turner AJ \& Hooper NM 2004 Evaluation of angiotensin-converting enzyme (ACE), its homologue ACE2 and neprilysin in angiotensin peptide metabolism. Biochemical Journal $\mathbf{3 8 3}$ 45-51. (doi:10.1042/BJ20040634)

Roks AJ, van Geel PP, Pinto YM, Buikema H, Henning RH, de Zeeuw D \& van Gilst WH 1999 Angiotensin-(1-7) is a modulator of the human renin-angiotensin system. Hypertension 34 296-301. (doi:10.1161/01. HYP.34.2.296)

Rowe BP, Saylor DL, Speth RC \& Absher DR 1995 Angiotensin-(1-7) binding at angiotensin II receptors in the rat brain. Regulatory Peptides 56 139-146. (doi:10.1016/0167-0115(95)00010-9)

Sampaio WO, Nascimento AA \& Santos RA 2003 Systemic and regional hemodynamic effects of angiotensin-(1-7) in rats. American Journal of Physiology. Heart and Circulatory Physiology 284 H1985-H1994.

Sampaio WO, Henrique de Castro C, Santos RA, Schiffrin EL \& Touyz RM 2007a Angiotensin-(1-7) counterregulates angiotensin II signaling in human endothelial cells. Hypertension 50 1093-1098. (doi:10.1161/ HYPERTENSIONAHA.106.084848)

Sampaio WO, Souza dos Santos RA, Faria-Silva R, da Mata Machado LT, Schiffrin EL \& Touyz RM 2007b Angiotensin-(1-7) through receptor Mas mediates endothelial nitric oxide synthase activation via Akt-dependent pathways. Hypertension 49 185-192. (doi:10.1161/01. HYP.0000251865.35728.2f)

Santos RA \& Ferreira AJ 2007 Angiotensin-(1-7) and the renin-angiotensin system. Current Opinion in Nephrology and Hypertension 16 122-128. (doi:10.1097/MNH.0b013e328031f362)

Santos RA, Brosnihan KB, Chappell MC, Pesquero J, Chernicky CL, Greene LJ \& Ferrario CM 1988 Converting enzyme activity and angiotensin metabolism in the dog brainstem. Hypertension $\mathbf{1 1}$ I153-I157. (doi:10.1161/01.HYP.11.2.153)

Santos RA, Brum JM, Brosnihan KB \& Ferrario CM 1990 The reninangiotensin system during acute myocardial ischemia in dogs. Hypertension 15 I121-I127. (doi:10.1161/01.HYP.15.2_Suppl.I121)

Santos RA, Brosnihan KB, Jacobsen DW, DiCorleto PE \& Ferrario CM 1992 Production of angiotensin-(1-7) by human vascular endothelium. Hypertension 19 II56-II61. (doi:10.1161/01.HYP.19.2_Suppl.II56)

Santos RA, Campagnole-Santos MJ, Baracho NC, Fontes MA, Silva LC, Neves LA, Oliveira DR, Caligiorne SM, Rodrigues AR, Gropen Junior C et al. 1994 Characterization of a new angiotensin antagonist selective for angiotensin-(1-7): evidence that the actions of angiotensin-(1-7) are mediated by specific angiotensin receptors. Brain Research Bulletin 35 293-298. (doi:10.1016/0361-9230(94)90104-X)

Santos RA, Simoes e Silva AC, Magaldi AJ, Khosla MC, Cesar KR, Passaglio KT \& Baracho NC 1996 Evidence for a physiological role of angiotensin-(1-7) in the control of hydroelectrolyte balance. Hypertension 27 875-884. (doi:10.1161/01.HYP.27.4.875)

Santos RA, Campagnole-Santos MJ \& Andrade SP 2000 Angiotensin-(1-7): an update. Regulatory Peptides 91 45-62. (doi:10.1016/S01670115(00)00138-5)

Santos RA, Haibara AS, Campagnole-Santos MJ, Simoes e Silva AC, Paula RD, Pinheiro SV, Leite MF, Lemos VS, Silva DM, Guerra MT et al. $2003 a$ Characterization of a new selective antagonist for angiotensin-(1-7), D-pro7-angiotensin-(1-7). Hypertension 41 737-743. (doi:10.1161/01. HYP.0000052947.60363.24) 
Santos RA, Simoes e Silva AC, Maric C, Silva DM, Machado RP, de Buhr I, Heringer-Walther S, Pinheiro SV, Lopes MT, Bader M et al. 2003b Angiotensin-(1-7) is an endogenous ligand for the $G$ protein-coupled receptor Mas. PNAS 100 8258-8263. (doi:10.1073/pnas.1432869100)

Santos RA, Ferreira AJ, Nadu AP, Braga AN, de Almeida AP, Campagnole-Santos MJ, Baltatu O, Iliescu R, Reudelhuber TL \& Bader M 2004 Expression of an angiotensin-(1-7)-producing fusion protein produces cardioprotective effects in rats. Physiological Genomics 17 292-299. (doi:10.1152/physiolgenomics.00227.2003)

Santos RA, Ferreira AJ, Pinheiro SV, Sampaio WO, Touyz R \& Campagnole-Santos MJ 2005 Angiotensin-(1-7) and its receptor as a potential targets for new cardiovascular drugs. Expert Opinion on Investigational Drugs 14 1019-1031. (doi:10.1517/13543784.14.8.1019)

Santos RA, Castro CH, Gava E, Pinheiro SV, Almeida AP, Paula RD, Cruz JS, Ramos AS, Rosa KT, Irigoyen MC et al. 2006 Impairment of in vitro and in vivo heart function in angiotensin-(1-7) receptor MAS knockout mice. Hypertension 47 996-1002. (doi:10.1161/01.HYP.0000215289. $51180.5 \mathrm{c})$

Santos EL, Reis RI, Silva RG, Shimuta SI, Pecher C, Bascands JL, Schanstra JP, Oliveira L, Bader M, Paiva AC et al. 2007 Functional rescue of a defective angiotensin II $\mathrm{AT}_{1}$ receptor mutant by the Mas protooncogene. Regulatory Peptides 141 159-167. (doi:10.1016/j.regpep.2006.12.030)

Santos SH, Fernandes LR, Mario EG, Ferreira AV, Porto LC, Alvarez-Leite JI, Botion LM, Bader M, Alenina N \& Santos RA 2008 Mas deficiency in $\mathrm{FVB} / \mathrm{N}$ mice produces marked changes in lipid and glycemic metabolism. Diabetes 57 340-347. (doi:10.2337/db07-0953)

Santos SH, Braga JF, Mario EG, Porto LC, Rodrigues-Machado Mda G, Murari A, Botion LM, Alenina N, Bader M \& Santos RA 2010 Improved lipid and glucose metabolism in transgenic rats with increased circulating angiotensin-(1-7). Arteriosclerosis, Thrombosis, and Vascular Biology 30 953-961. (doi:10.1161/ATVBAHA.109.200493)

Sasaki S, Higashi Y, Nakagawa K, Matsuura H, Kajiyama G \& Oshima T 2001 Effects of angiotensin-(1-7) on forearm circulation in normotensive subjects and patients with essential hypertension. Hypertension $\mathbf{3 8}$ 90-94. (doi:10.1161/01.HYP.38.1.90)

Savergnini SQ, Beiman M, Lautner RQ, de Paula-Carvalho V, Allahdadi K, Pessoa DC, Costa-Fraga FP, Fraga-Silva RA, Cojocaru G, Cohen Y et al. 2010 Vascular relaxation, antihypertensive effect, and cardioprotection of a novel peptide agonist of the MAS receptor. Hypertension $\mathbf{5 6}$ 112-120. (doi:10.1161/HYPERTENSIONAHA.110.152942)

Schiavone MT, Santos RA, Brosnihan KB, Khosla MC \& Ferrario CM 1988 Release of vasopressin from the rat hypothalamo-neurohypophysial system by angiotensin-(1-7) heptapeptide. PNAS $\mathbf{8 5} 4095-4098$. (doi:10.1073/pnas.85.11.4095)

Schling P, Mallow H, Trindl A \& Loffler G 1999 Evidence for a local renin angiotensin system in primary cultured human preadipocytes. International Journal of Obesity and Related Metabolic Disorders 23 336-341. (doi:10.1038/sj.ijo.0800821)

Sihn G, Rousselle A, Vil'ianovich L, Burckle CA \& Bader M 2010 Physiology of the (pro)renin receptor: Wnt of change? Kidney International $\mathbf{7 8}$ 246-256. (doi:10.1038/ki.2010.151)

Silva DM, Vianna HR, Cortes SF, Campagnole-Santos MJ, Santos RA \& Lemos VS 2007 Evidence for a new angiotensin-(1-7) receptor subtype in the aorta of Sprague-Dawley rats. Peptides 28 702-707. (doi:10.1016/ j.peptides.2006.10.007)

Silveira KD, Pompermayer Bosco KS, Diniz LR, Carmona AK, Cassali GD, Bruna-Romero O, de Sousa LP, Teixeira MM, Santos RA, Simoes e Silva AC et al. 2010 ACE2-angiotensin-(1-7)-Mas axis in renal ischaemia/ reperfusion injury in rats. Clinical Science 119 385-394. (doi:10.1042/ CS20090554)

Simoes e Silva AC, Bello AP, Baracho NC, Khosla MC \& Santos RA 1998 Diuresis and natriuresis produced by long term administration of a selective angiotensin-(1-7) antagonist in normotensive and hypertensive rats. Regulatory Peptides 74 177-184. (doi:10.1016/S01670115(98)00038-X)
Soares de Moura R, Resende AC, Emiliano AF, Tano T, Mendes-Ribeiro AC, Correia ML \& de Carvalho LC 2004 The role of bradykinin, $\mathrm{AT}_{2}$ and angiotensin 1-7 receptors in the EDRF-dependent vasodilator effect of angiotensin II on the isolated mesenteric vascular bed of the rat. British Journal of Pharmacology 141 860-866. (doi:10.1038/sj.bjp. 0705669)

Soler MJ, Wysocki J, Ye M, Lloveras J, Kanwar Y \& Batlle D 2007 ACE2 inhibition worsens glomerular injury in association with increased ACE expression in streptozotocin-induced diabetic mice. Kidney International 72 614-623. (doi:10.1038/sj.ki.5002373)

Stanziola L, Greene LJ \& Santos RA 1999 Effect of chronic angiotensin converting enzyme inhibition on angiotensin I and bradykinin metabolism in rats. American Journal of Hypertension 12 1021-1029. (doi:10.1016/S0895-7061(99)00090-4)

Stegbauer J, Oberhauser V, Vonend O \& Rump LC 2004 Angiotensin-(1-7) modulates vascular resistance and sympathetic neurotransmission in kidneys of spontaneously hypertensive rats. Cardiovascular Research $\mathbf{6 1}$ 352-359. (doi:10.1016/j.cardiores.2003.11.017)

Stegbauer J, Potthoff SA, Quack I, Mergia E, Clasen T, Friedrich S, Vonend O, Woznowski M, Konigshausen E, Sellin L et al. 2011 Chronic treatment with angiotensin-(1-7) improves renal endothelial dysfunction in apolipoproteinE-deficient mice. British Journal of Pharmacology 163 974-983. (doi:10.1111/j.1476-5381.2011.01295.x)

Su Z, Zimpelmann J \& Burns KD 2006 Angiotensin-(1-7) inhibits angiotensin II-stimulated phosphorylation of MAP kinases in proximal tubular cells. Kidney International 69 2212-2218. (doi:10.1038/sj.ki. 5001509)

Tallant EA \& Clark MA 2003 Molecular mechanisms of inhibition of vascular growth by angiotensin-(1-7). Hypertension 42 574-579. (doi:10.1161/01.HYP.0000090322.55782.30)

Tallant EA, Ferrario CM \& Gallagher PE 2005 Angiotensin-(1-7) inhibits growth of cardiac myocytes through activation of the mas receptor. American Journal of Physiology. Heart and Circulatory Physiology 289 H1560-H1566. (doi:10.1152/ajpheart.00941.2004)

Tipnis SR, Hooper NM, Hyde R, Karran E, Christie G \& Turner AJ 2000 A human homolog of angiotensin-converting enzyme. Cloning and functional expression as a captopril-insensitive carboxypeptidase. Journal of Biological Chemistry 275 33238-33243. (doi:10.1074/jbc. M002615200)

Tom B, de Vries R, Saxena PR \& Danser AH 2001 Bradykinin potentiation by angiotensin-(1-7) and ACE inhibitors correlates with ACE Cand N-domain blockade. Hypertension 38 95-99. (doi:10.1161/01.HYP. 38.1.95)

Velez JC, Ierardi JL, Bland AM, Morinelli TA, Arthur JM, Raymond JR \& Janech MG 2012 Enzymatic processing of angiotensin peptides by human glomerular endothelial cells. American Journal of Physiology. Renal Physiology 302 F1583-F1594. (doi:10.1152/ajprenal. 00087.2012)

Velkoska E, Dean RG, Griggs K, Burchill L \& Burrell LM 2011 Angiotensin(1-7) infusion is associated with increased blood pressure and adverse cardiac remodelling in rats with subtotal nephrectomy. Clinical Science 120 335-345. (doi:10.1042/CS20100280)

Verano-Braga T, Schwammle V, Sylvester M, Passos-Silva DG, Peluso AA, Etelvino GM, Santos RA \& Roepstorff P 2012 Time-resolved quantitative phosphoproteomics: new insights into angiotensin-(1-7) signaling networks in human endothelial cells. Journal of Proteome Research 11 3370-3381. (doi:10.1021/pr3001755)

Vickers C, Hales P, Kaushik V, Dick L, Gavin J, Tang J, Godbout K, Parsons T, Baronas E, Hsieh F et al. 2002 Hydrolysis of biological peptides by human angiotensin-converting enzyme-related carboxypeptidase. Journal of Biological Chemistry 277 14838-14843. (doi:10.1074/jbc. M200581200)

Walters PE, Gaspari TA \& Widdop RE 2005 Angiotensin-(1-7) acts as a vasodepressor agent via angiotensin II type 2 receptors in conscious rats. Hypertension 45 960-966. (doi:10.1161/01.HYP.0000160325. 59323.b8) 
Wang LJ, He JG, Ma H, Cai YM, Liao XX, Zeng WT, Liu J \& Wang LC 2005 Chronic administration of angiotensin-(1-7) attenuates pressure-overload left ventricular hypertrophy and fibrosis in rats. Di Yi Jun Yi Da Xue Хие Вао 25 481-487.

Wiemer G, Dobrucki LW, Louka FR, Malinski T \& Heitsch H 2002 AVE 0991, a nonpeptide mimic of the effects of angiotensin-(1-7) on the endothelium. Hypertension 40 847-852. (doi:10.1161/01.HYP. $0000037979.53963 .8 \mathrm{~F})$

Wysocki J, Ye M, Soler MJ, Gurley SB, Xiao HD, Bernstein KE, Coffman TM, Chen S \& Batlle D 2006 ACE and ACE2 activity in diabetic mice. Diabetes 55 2132-2139. (doi:10.2337/db06-0033)

Xu P, Costa-Goncalves AC, Todiras M, Rabelo LA, Sampaio WO, Moura MM, Santos SS, Luft FC, Bader M, Gross V et al. 2008 Endothelial dysfunction and elevated blood pressure in MAS gene-deleted mice. Hypertension 51 574-580. (doi:10.1161/HYPERTENSIONAHA.107. 102764)

Yamamoto K, Ohishi M, Katsuya T, Ito N, Ikushima M, Kaibe M, Tatara Y, Shiota A, Sugano S, Takeda S et al. 2006 Deletion of angiotensin-converting enzyme 2 accelerates pressure overload-induced cardiac dysfunction by increasing local angiotensin II. Hypertension 47 718-726. (doi:10.1161/01. HYP.0000205833.89478.5b)

Yusuf S, Gerstein H, Hoogwerf B, Pogue J, Bosch J, Wolffenbuttel BH \& Zinman B 2001 Ramipril and the development of diabetes. Journal of the American Medical Association 286 1882-1885. (doi:10.1001/jama.286. $15.1882)$
Zhang J, Noble NA, Border WA \& Huang Y 2010 Infusion of angiotensin-(1-7) reduces glomerulosclerosis through counteracting angiotensin II in experimental glomerulonephritis. American Journal of Physiology. Renal Physiology 298 F579-F588. (doi:10.1152/ajprenal. 00548.2009)

Zhong J, Guo D, Chen CB, Wang W, Schuster M, Loibner H, Penninger JM, Scholey JW, Kassiri Z \& Oudit GY 2011 Prevention of angiotensin IImediated renal oxidative stress, inflammation, and fibrosis by angiotensin-converting enzyme 2. Hypertension 57 314-322. (doi:10.1161/HYPERTENSIONAHA.110.164244)

Zhou L, Xue H, Wang Z, Ni J, Yao T, Huang Y, Yu C \& Lu L 2012 Angiotensin-(1-7) attenuates high glucose-induced proximal tubular epithelial-to-mesenchymal transition via inhibiting ERK1/2 and p38 phosphorylation. Life Sciences 90 454-462. (doi:10.1016/j.lfs. 2011.12.015)

Zhu Z, Zhong J, Zhu S, Liu D, Van Der Giet M \& Tepel M 2002 Angiotensin(1-7) inhibits angiotensin II-induced signal transduction. Journal of Cardiovascular Pharmacology 40 693-700. (doi:10.1097/00005344200211000-00007)

Zimmerman D \& Burns KD 2012 Angiotensin-(1-7) in kidney disease: a review of the controversies. Clinical Science 123 333-346. (doi:10.1042/ CS20120111)

Zisman LS, Meixell GE, Bristow MR \& Canver CC 2003 Angiotensin-(1-7) formation in the intact human heart: in vivo dependence on angiotensin II as substrate. Circulation 108 1679-1681. (doi:10.1161/ 01.CIR.0000094733.61689.D4)

Received in final form 18 October 2012

Accepted 22 October 2012

Accepted Preprint published online 22 October 2012
C 2013 Society for Endocrinology Printed in Great Britain
Published by Bioscientifica Ltd. 